\title{
Değişen Kamusallığın Yeni "Siyaset Yapma" Mekânı Olarak Sosyal Medya - (Politik Kimlikler ile Kamusal Haklar İlişkisi Bağlamında Twitter Örneği)
}

\author{
DOI: 10.26466/opus.520312 \\ * \\ $\underline{\text { Yavuz Çobanoğlu }}{ }^{*}$
}

*Dr. Öğr. Üyesi,Munzur Üniversitesi Edebiyat Fakültesi,Tunceli/ Türkiye E-Posta: yavuzcobanoglu@hotmail.com O ORCID: 0000-0001-9144-2389

\section{Öz}

Bu çalışmanın amact, iletişim teknolojilerindeki gelişmeler neticesinde artık geniş kitlelerce kullanılmaya başlanan ve yeni bir kamusal alan olarak kabul gören sosyal medyadaki politik kimliklerin sunumları bağlamında "siyaset yapma" ilişkileri üzerinedir. Sosyal medya günümüzde artık sadece politik kimliklerin sergilendiği bir mekân değil, kamusal hak taleplerinin de dile getirildiği toplumsal bir alandır. Hatta bu taleplerin etkileri ve gerçekleşme şansları düşünüldüğünde, sosyal medyanın klasik kamusal alandan daha işlevsel olduğu da söylenebilir. Böylelikle sosyal medya ortamlarında sergilenen politik kimliklerin kamusal haklara bakışı ve kamusal taleplere yaklaşım biçimleri de merak uyandırmaktadır. Dolayısıyla bu makale, sosyal medyada yaygin siyaset yapma mekânlarından birisi olan Twitter'da böylesi bir merakın peşine düşecektir. Çalışmanın araştırma tekniği olarak içerik analizi yöntemi seçilmiştir. Türkiye'de yaygin politik düşünceler olarak geniş anlamda kabul gören, "İslâmcıllk", "Müslümanlık", "solculuk", "sosyalistlik", "Türkçülük" ve "milliyetçilik" kelimeleri, kamusal talepler olan "demokrasi”, “özgürlük", "haklar", "inanç", “özel hayat", "mülkiyet”, "güvenlik”, “kanun", “Anayasa" gibi kavramlarla da çaprazlama eşleştirilip Twitter modülü üzerinden taratılmıştır. Tarama sonucunda çalışmaya katkı sunabileceği düşünülen twit'lerin ekran görüntüleri alınmış, bu twit'lerde geçen söylemler tasnif edilerek seçilen politik kimliklerin kamusal bir mekân olan sosyal medyada nasıl ve hangi bă̆ lamlarla birlikte kullanıldığı tespit edilmeye çalışılmıştır.

Anahtar Kelimeler: Kamusal Alan, Politik Kimlikler, Sosyal Medya, Kamusal Haklar, Twitter 


\title{
Social Media as The New Venue of "Political Activity" of The Changed Publicity - (The Case of Twitter in The Context of The Relations Between Political Identities and Public Rights)
}

\begin{abstract}
The aim of this study deals with 'doing politics' as a part of the presentation of political identities on social media which has been used widely and recognized as a new public sphere as a result of advanced communication Technologies. Social media is not only a space where political identities are presented but also a public sphere in which civil rights are demanded. When the impact of these demands and their chance of success are considered, it can be said that social media is more functional than a classical public sphere. Thus, the way these political identities presented on social media handle public rights and demands arouses interest. That is the reason why this article pursue this very interest on Twitter, one of the widely used spaces for doing politics on social media. Content analysis method is chosen as the main method of this study. The words/terms which are widely accepted as common political ideas in Turkey such as "Islamism", "Muslimism", "leftism", "socialist", "Turkism" and "nationalism" was cross matched with public demands such as "democracy", "rights", "freedom", "faith", "private life", "ownership", "security", "law", "Constitution" and searched on Twitter module. As a result of this search screenshots of some tweets which could contribute to this study were captured and by classifying the discourses stated through these tweets, how the chosen political identities are used within some certain context on social media as a public sphere is figured out.
\end{abstract}

Keywords: Public Space, Political Identities, Social Media, Public Rights, Twitter 


\section{Giriş}

İnsan, toplum ve devlet ile bunların arasındaki münasebetler söz konusu olduğunda, sosyolojik araştırmanın merakı siyasal olan'a yönelmektedir. Oysaki siyasal olan'ın tespiti, esasen ontolojik bir duruma işaret eder. Onun ontolojisi, neyin/nelerin, hangi şartlarda "siyasal" olarak ele alınabileceği ve siyaset açısından nasıl anlaşılır kılınabileceği üzerinedir. Zaten siyaset sosyolojisinin de böylesi bazı gereklilikler sonucu olarak ortaya çıktığı söylenebilir ve bu gereklilikler esasen, siyaset ile onun etrafında şekillenen olguları, sosyolojinin paradigmalarıla anlama zorunluluğunun bir sonucudur. Böylelikle siyaset sosyolojisi, siyasal sistem, hayat ve ona dair aktörleri; siyasal düşüncelerin ürettiği tepkiler ile davranışları; ideolojiler, semboller, dil ve söylemlerin kitleler üzerindeki etkilerini; güç ve iktidar ilişkilerini; toplumsal yapılar ile örgütlenme şekillerini; demokrasi ve parlamenter kurumların işleyişini; toplum ve devlet arasındaki farklılaşmalar vb. ile bunların sebepleri ve etkilerine dair bilgi üretmeye çalışılan bilimsel bir alan olarak doğup, gelişmiştir.

Üstelik bu alanda olup bitenler sadece siyaset sosyolojisiyle değil, sosyolojinin pek çok alanıyla da yakından ilgilidir. Örneğin, sayısız şekillerde görüleceği üzere, "dinî olan" ile "siyasî olan" çoğu kez iç içe geçmiştir. Dinsel duygular, söylemler, anlatılar, zihniyet biçimleri, semboller, temsiller, ritüeller, giyim şekilleri gibi vb. özellikler, farklı amaçlar doğrultusunda ve yoğun olarak politik alanda karşımıza çıkmaktadır. Bunlar, bu alanda, çoğu kez "talepler" biçiminde yer bulsalar da özellikle aktif siyaset söz konusu olduğunda, "dinî olan" ile onun çevrelediği tüm sosyal gerçeklikler, bir birliktelik ilişkisi içerisinde seyrederler. Bu sebeple, bilimsel bir merak eşliğindeki bir araştırmacının analiz nesnesi siyaset, kültür, din, inanç, zihniyet vb. olduğunda, siyaset sosyolojisi ile dinî olan'ın, din sosyolojisi ile siyasal olan'ın sınırları her zaman net ve belirgin değildir. Bu belirsizlik, siyaset ile din ilişkisini de kapsamak kaydıyla, siyaset olgusunu bütünsel bir açıdan ele alan "politik kültür" yaklaşımı ve çözümlemeleri üzerinden aşılmaya çalışılmıştır. Çünkü "politikayı kuşatan maddî koşullar, kültüre göre öncelikli değildir. Kültür, maddî çıkarların adlandırılmasında ve gerçekleştirilmesi için başvurulan etkinliklerde hayatî bir rol oynamaktadır. Dolayısıyla politik kültür bütün bir politik sürece egemendir" (Sarıbay ve Öğün,1998, s.89). Bu yüzden politik 
kültür çalışmaları, bir yandan kültürün sosyal ve politik süreçlerdeki etkilerini araştırırken, diğer taraftan da siyaseti ve dini de içerisine alan çok daha geniş ölçekli bir kapsama sahiptir. Alanın içerik bakımından çeşitliliği ve zenginliği de zaten bu özelliğinden kaynaklanmaktadır.

Bununla birlikte, insan eylemleri ile ona bağlı olan tüm sosyal pratiklerin konusu da siyaset sosyolojisinin temel ilgi alanına girer. Buna göre, bazen bilinçli bir politik amaca sahip olmasa bile benzer sosyal pratiklerin ortaya çıkardığı, ürettiği, beslediği ve şekillendirdiği toplumsal ilişki biçimleri de "siyaset yapma" adıyla ifade edilir. Genel itibarıyla popüler anlamda ve günlük dilde geçerlilik kazanan bu ifade, inanılan bir takım politik düşünceleri, dünya görüşlerini veya ideolojik tercihleri karşıdaki kişilere/gruplara iletişim yoluyla anlatma, sunma ya da kabul ettirmeye çalışma süreçlerini de içerir. Özellikle "devlet yönetimi” söz konusu olduğunda buradaki asıl kaygı, siyaset aracılığıyla kontrolü ele geçirme ya da elde tutmaya yöneliktir. Bu yüzden "siyaset yapma" esasen kişiler ile gruplar arasındaki güç ve iktidar mücadelesine tekabül eder. Yine de bilhassa günümüzde " 'siyasal' olanın alanı, sadece devlet ile sınırlanmayacak kadar genişlemiştir" (Sarıbay, 1998, s.13). Bu genişleme de, özellikle siyasal olan söz konusu olduğunda, araştırmacıları artık özellikle kültürel olgulara doğru yönlendirmektedir. Keza aynı ilgi neticesinde, bu makalenin merak konusu da yeni ve kitlesel olarak kültürel (dahası siyasal) bir mekân şeklinde kullanılan sosyal medyada sergilenen kimlik sunumları olacaktır. Tabi bütün bunlar cereyan ederken, değişen bir kamusallık ile zemini sosyal medyaya kayan bir kamusal mekân anlayışına da bakmak bu makalenin mecburiyetleri arasindadır.

\section{Kamusal Alan ve Değişen Kamusallık Anlayışı}

Kamu, kamusal alan ve kamusallık kavramlarının referansı kadim çağlara dayansa da bu kavramlara yönelik tartışmaların yoğunlaştığ aralığı, esasen modern döneme rastlamaktadır. Zira modern dönemle birlikte, ulus devlet, sivil toplum, vatandaşlık hakları, demokrasi, birey ve özgürlük gibi pek çok kavrama dair tartışma, hem de tarihte hiç görülmeyen bir yoğunlukla, sosyal bilimlerin merkezine yerleşmişti. Böylece kamusal alan, tüm vatandaşların hiçbir sınır ya da engelle karşılaşmadan, kamu imkânlarını da kullanarak, birbirleriyle açı bir 
şekilde ve her türlü yoldan iletişime geçmeleri aracılığıyla yaratılan ortak toplumsal etkinlik mekânını ifade eder bir hâle geldi. Vatandaşlar da sadece anayasal bir düzenin getirdiği kurallara tabi olmak kaydıyla, bu alanı kullanabilme hakkını elde ettiler. Fakat bazı sınırlara sahip bu "haklar"1n denetimi mevzubahis olduğunda, devletin buradaki pozisyonu artık tartışma konusu haline gelmeye de başladı. Zira vatandaşların kamusal alana dair talepleriyle (örneğin, çıar, baskı ve buyruklardan bağımsız bir kamu alanı gibi) devletin bu alandaki mevcut egemenliği, pek çok açıdan çatışmaktaydı. Dolayısıyla bu durum, toplum ile devlet arasında "aracılık" işlevi gören bu alanın hem varoluş amacını hem de meşruiyetini zedeledi. Bu sebeple, iki kutbun da kamusal alan üzerindeki sorumluluk ile etki hudutlarını belirlemek gerekliliği hasıl oldu. Buradaki tartışma büyürken, bu hudutların belirlenmesi adına "kamusal alan" denildiğinde akla gelen ilk isim olan Jürgen Habermas, modern demokrasinin toplumsal kökenlerini araştırırken toplum ile devlet arasındaki durumun, demokratik talep ve otorite arasındaki ilişki üzerinden düşünülmesi gerektiğine işaret etti. Öyle ki,

"Her ne kadar devlet otoritesi siyasal kamu alanında icra etmekten (execute) sorumlu olsa da, bu alanın bir parçası değildir. Devlet otoritesi, genellikle, 'kamu' otoritesi olarak kabul edilir; devletin vatandaşların refahını sağlama sorumluluğu kamusal alanın bu işlevinden kaynaklanır. Sadece siyasal kontrolün icra edilmesi gözle görülür bir şekilde her vatandaşın kendisini bilgilendirecek araçlara sahip olabilmesini gerektiren demokratik talebe yenik düştügünde, kamusal alan yasal organlar aracılığ1 ile hükümeti kurumsal yollarla etkileme şansına sahip olur. Kamuoyu deyimi, bu bağlamda, kontrol ve eleştiriye tekabül eder. Söz konusu kontrol ve eleştiri, devlet biçiminde örgütlenmiş egemen bir yap1 aracılığı ile vatandaşların oluşturduğu bir kamu organı tarafından informel bir şekilde -ve seçimler yoluyla, formel bir şekilde- uygulanır. Bu türden uygulamaların kamuya açık olmalarını gerektiren yasal düzenlemeler de kamusal alanın bu işleviyle ilgilidir. Devlet içinde, bilindiği gibi kamu, kendisini kamuoyunun taşıyıcısı olarak örgütler; toplum ve devlet arasında aracilık yapan kamusal alan da kamusal alanının bu en önemli ilkesi ile uyum içindedir - bir zamanlar kendisi adına monarşilerle savaşılan söz konusu ilke ve o zamandan bu yana devletin etkinliklerinin 
demokratik kontrolünü olası kılan ilkeden bahsetmekteyiz" (Habermas, 1995, s.63-63).

Buna göre vatandaşlar, kamusal alandaki yasal yollar üzerinden hükümeti/devleti etkileme ya da denetleme hakkına sahiptirler. "Kamuoyu" deyimi de zaten bunun için vardır. Kendi teorisi ve onun etrafındaki tüm kavramları liberal bir düzlemde düşünen Habermas'ın burada kamusal alandan kastı, tüm vatandaşların hiçbir kısıtlamaya maruz kalmadan bu alana girebilme, orada toplanma ve her konuda düşünebilme haklarının olduğu; ortak fikirlerin burada oluşup, biçimlendiği kolektif bir mekânda ifadesini bulur. Bu mekân, düşünce özgürlüğü, örgütlenme yeri olduğu kadar, inanç ve kimliklerin de başkalarına sunulduğu bir alandır. Bu nokta önemlidir; zira aşağıda soysal medyanın da esasen "yeni bir kamusal alan" olduğunu, "kamuoyu oluşturma" özelliğinin klasik kamusal alanların imkânlarından sanal ortamlar olan sosyal medyaya intikal ettiğini tartışırken bu bilgileri anımsamaya ihtiyaç duyacağız. Neticede Habermasçı kamusal alan kavramlaştırması;

"Modern toplumlarda, politik katılımın (talk) ortamı aracılığıyla icra edildiği bir sahneye işaret ediyor. Bu, yurttaşların ortak meseleleri hakkında müzakerede (deliberate) bulundukları bir alan; yani, kurumsallaşmış bir söylemsel etkileşim alanı. Bu alan kavramsal olarak devletten ayrı olan; ilke olarak da devlete karşı eleştirel söylemlerin üretildiği ve dolaştırıldığı bir alana" karşılık gelir (Fraser, 2004, s.104).

Temsili demokrasinin önündeki "meşruiyet krizi"nin çözümüne yönelik bir çaba olarak nitelendirilebilecek olan Habermas'ın kamusal alan kuramı, konunun karmaşıklığı da dikkate alındığında, sosyoloji, ekonomi, kamu hukuku ve siyaset bilimi gibi farklı bilimsel disiplinleri kapsayan "disiplinler arası bir yöntemle" ve tarihselci bir bakış açısının yardımıyla aktarılmaya çalışıldığ görülmektedir (Habermas, 1997, s.910). Habermas'a göre “ 'kamusal' ve 'kamu' kavramlarının günlük dildeki kullanımı, her iki sözcügün de birbiriyle uyuşmayan çok çeşitli anlamlara sahip olduğunu ele" vermektedir; çünkü "değişik tarihsel evrelerden kaynaklanan bu anlamlar, sanayisi gelişmiş ve sosyal devlet olarak örgütlenmiş burjuva toplumu koşullarına eşzamanlı olarak uygulanan kullanımları içinde, birbirleriyle bulanık bir ilişkiye" girmelerinden kaynaklanır (Habermas, 1997, s.57). Meşhur çalışmasında kamu ve özel alana dair klasik "ayrım"1 devam ettiren Habermas, kamuoyunun 
taşıyıcısının "halk" olduğunu söyler. Zira "kamu, kendisini, özel alandan ayrı bir alan olarak ortaya koyar. Bazen de kendisini çok basit düzeyde, kamu gücünün karşıtı bir alan olarak, kamuoyu alanı görünümünde sunar. Duruma göre, kimi kez devlet organları, kimi kez de halkın iletişimine hizmet eden basın gibi medya unsurları 'kamusal organlar' arasında sayılır" (Habermas, 1997, s.58-60). Böylece iletişimin aracisı olarak medya, esasen, hem modern dönemin ruhunun bir yansıması hem de insan ilişkileri bağlamında demokratik kamusallığın özü biçiminde değerlendirilebilir. Zaten bu yönüyle de Habermasçı teori, modernitenin bitmeyen bir proje olduğunun kararlı taahhüdüyle, iletişim politikalarının eleştirel analizinden etkilenmiş olan bir bakış açısıdır (McGuigan, 1996, s.5).

Örneğin Ortaçağ'da özel alandan ayrı biçimde düşünülebilecek bir kamu alanı yokken, modern çağ ile birlikte (yeni ve sosyo-ekonomik bir sınıf olarak burjuvaların çabaları da yadsınamaz) siyasal bir kamu alanı doğmuştur. Entelektüel ortamlardaki kapitalist girişimci ve aristokratların oluşturduğu sohbetlerle güçlenen politik bir eleştiri düşüncesi zamanla gelişip, bu kolektif alanlardaki ortak ilişkileri yine bu alana özgü bir niteliğe büründürmüştür. Sonrasında ilginç bir biçimde kamusal bir akıl yürütme faaliyetine dönüşen bu nitelik, devlet iktidarının hem dışında hem de karşısında yeni bir tartışma mekânı üreterek "sivil" bir alanın doğuşuna neden olmuştur. Öyle ki, sohbet ortamlarına olanak sağlayan kafeler, tiyatrolar, karşılıklı sohbet imkânı sağlayan salonlar, kahvehaneler gibi vb. yerler, ülke çapında yaygınlaştıkça, kamusal alanın etki sınırları da aynı ölçüde genişlemiştir. Dahası özgürce konuşma ve eleştirme gücü, devletten bağımsız bu özerk alanların siyasal bir boyut kazanmalarına da neden olmuştur. Habermas'a göre bütün bu gelişmeler, demokratik yeniden üretimi mümkün kılan böylesi iletişimsel ortamların sonucudur (Habermas, 1997, s.135-180). Bu ortamlar, kolektif çıkarlara dayalı oldukları için, kendi meşruiyetini de kendi bağrından üretmiştir. Keza, "kamusal alan, bireylerin açı tartışmalara katılmak için toplandıkları bir yerdir. Potansiyel olarak herkes erişime sahiptir ve kimse bu alanda bir diğerine göre bir avantajla burada konuşmaya giremez. Bunlar kamusal alanın tarihsel bağlamda kabul gören genel niteliklerindendir" (Holub, 1991, s.4). Böylesi bir kabul görmenin olası meşruiyet problemlerini, hem de daha en baştan, ortadan kaldırdığı da söylenebilir. 
Yine de Habermas'ın kamusal alan teorisi, pek çok açıdan problemlidir. Öncelikle merkezî devlet karşısında "burjuva kamusallığı"nı tercih ettiği bilinen Habermas, aynı burjuva sınıfının güçlendikten sonra demokratik dengeleri kendi lehine çevirme konusundaki iştahı ile kamusal müzakere alanlarını (bazen de zor kullanarak) kontrol etme isteği gibi konulara değinmez. Üstelik, Habermasçı kamusal alan kavramlaştırmasının ekonomik temelleri de zayıftır. Mülkiyet, üretim ilişkileri ve burjuva sınıfı dışındaki sınıfsal farklılıkların bu alandaki etkileri, onun teorisinin eksik sayılabilecek diğer yanlarıdır. Özetle,

“Habermas'ın müzakereci bir demokrasi için idealize ettiğ $i$ kamusallık biçimi, ifade edilen tartışma bă̆lamında, sinırları dar tanımlanmış bir söylemsel alana karşıllk gelmektedir. Burjuvazinin toplumsal bir kategori olarak palazlanma çabası sonucunda elde edilen demokratik ilerlemenin sinufsal karakteri demokrasiyi mümkün kılan müzakere sürecinin derinleşememesine yol açmıştır. Böylelikle tanınma sisteminin kurulmadığ kânı bulamaması dolayısıyla özneleşemediği bir yapı ortaya çıkmaktadır. Bu durum demokrasisiz bir demokrasinin oluşumuna neden oluyor gözükmektedir" (Minarl, 2014, s.169).

Diğer taraftan, doğal olarak kamusal alan kavramlaştırmaları Habermas'ın "burjuva kamusal alanı" teorisiyle de sinırlı değildir. Hannah Arendt'in "cumhuriyetçi kamusal alanı", John Rawls'ın "liberal kamusal alan" teorisi, Richard Sennett'in "kamusal insanın çöküşü"ne dair tartışmaları da konu üzerine değerli katkılardandır. Örneğin Hannah Arendt'in kavramını teorileştirmeye çalıştığı zaman dilimi, Habermas'ın burjuva kamusallı̆̆ının ortaya çıtığı modern dönemin aksine, Antik Yunan'daki Polis'in kamusallığına denk düşer. Dahası Arendt'e göre, kamusal alan ile özel alan ayrımının ortaya çıkışı da Polis'in doğuşuyla mümkün olmuştur. Zira bir kent devleti olarak Polis'in tarih sahnesine çıkışıyla birlikte, vatandaşlar için artık iki ayrı "varoluş" düzeyine (özel kendine ait- ve kamusal -ortak-) geçmişlerdir. Arendt mecbur olarak "katlanılan" hane ile serbestliklerin yaşandığı siyasal alan arasındaki bu ikili ayrımın yanına, yeni bir kavram daha ekler: Toplumsal alan ${ }^{1} \ldots$ Bu

\footnotetext{
${ }^{1}$ Arendt'in "toplumsal alan" kavramının geniş bir açıklaması için bknz: Arendt, H. (1994), insanlık Durumu / Seçme Eserler, (Çev: Bahadır Sina Şener), Iletişim Yayınları, İstanbul, 1. Baskı, s. 39-105
} 
kavram, ortaya çıkış koşullarını modern devlet içerisinde bulan, siyasî tezahürü millî devlet ile taçlanmış bir sosyal gerçekliğe karşılık gelmektedir. Çünkü "toplumun, kamusal olarak örgütlenmiş bizatihi yaşam süreci olduğunun belki de en açık göstergesi, yeni toplumsal alanın oldukça kısa bir sürede bütün modern toplulukları emekçilerden ve iş sahiplerinden oluşma toplumlar haline dönüştürmüş olmasında görülebilir; başka bir deyişle hepsi de aynı anda yaşamı sürdürmek için gerekli o tek faaliyetin etrafında odaklanmışlardır" (Arendt, 1994, s.69). Yine de Arendt, kamu ile özel alan arasındaki bir ara pozisyonda konumlandırdığ ve burada olup bitenleri, olumlamaz.

Öyle ki, “toplumsal alanın yükselişi onları (insanlar Y.Ç.) mahrem ve özel alana sürdüğünden beridir konuşma ve eylem yeteneğimiz eski niteliğinden pek çok şey kaybetti ve bizler kamu alanında yerine getirdiğimiz emekle mükemmel olmaya başladık" diye yazar (Arendt, 1994, s.73). Zaten modern devlette emekle "mükemmel olmaya" çalışmak, aslen insan eylem ve düşüncelerini kilitlemektedir. Üstelik ona göre modern yaşayışta toplumsal alan ile politik alan arasındaki uzaklık, Antik Yunan Polis'indekine nazaran fazlasıyla azalmıştır. Modern hayat, evde çalışma ve üretim imkânlarını evden uzaklaştırmış, ev ile iş mekânsal olarak ayrılmış, özel alana dâhil olan tüm durumlar (aile, iş, mutluluk, hatta aşk bile vb.) bir ekonomik etkinliğe (kolektif bir hâle) indirgenmiştir. Böylelikle modern dünyada kamu ve özel ayrımı ortadan kalkmış, bu alanlar artık birbirine karışmıştır. Yine de toplumsal alan, insanın görülebilir ve duyulabilir olması açısından ayrı bir öneme sahiptir ve insanın bir gerçeklik biçiminde tezahür etmesi açısından zorunludur. Bu yüzden Arendt bu alana "görünümler sahnesi" adını verir. İnsanlar burada birbirlerine üstünlük kurmak, uyum içinde hareket etmek, itibar görmek, konuşmak, ikna etmek gibi vb. eylemler için bulunurlar. Hatta "konuşma (rhetoric/söz/lexis)", eylem ile birlikte "en önemli insanî vasıf (Arendt, 1994, s.43), insan olmanın "birinci şartı" dır (Arendt, 1994, s.240-247). Ona göre "konuşmanın ve eylemin olmadığı bir yaşam, harfiyen, yaşarken ölmek demektir" (Arendt, 1994, s.241). İnsanlar arasında geçirilmeyen zaman, yaşamin sona ermesidir.

Bununla birlikte Arendt kamusal alana bakışını felsefî bir kavram olan etik üzerinden de biçimlendirir ve onun metinlerinde bilinçli ya da bilinçsizce kamu alanından kendisini dışlamış, evine hapsolmuş insanlar 
"fakirleşmiş" olarak nitelendirilirken "idiotik" kavramı kullanılır (Arendt, 1994, s.59). Zira Antik Yunan'da siyasetin dışında kalan ve siyasetle ilgilenmeyen insanlar "idiot" olarak ifade edilir (Kerestecioğlu, 2011, s.159). Bunlar sadece kendilerine ait yaşamları olan insanlardır ve kamusal alan ya da toplumsal alanda varolarak hayatını zenginleştirmektense, tamamıla özel yaşamda hayatlarını devam ettirerek hakiki bir insani yaşam için özsel olan şeylerden yoksun kalırlar. Çünkü hanede (/oikos), kaçınılmaz bir zorunluluk egemendir ve tüm zorunluluk ilişkileri de yine hane içerisine sıkışmıştır. Dahası bu şekilde "başkaları tarafından görülmenin ve duyulmanın sağladığı gerçeklikten; başkalarıyla ortak bir şeyler dünyası aracılığıyla birleşmenin ve ayrılmanın sağladığı 'nesnel' bir ilişkiden, yaşamın kendinden daha kalıcı bir şeyler başarma olanağından da yoksun" kalmaktadırlar (Arendt, 1994, s.86 vd.). Sonuç itibarıyla, kamusal, özel veya toplumsal hangi alan ele alınırsa alınsın, bu kavramsal ayrımların Arendt'te ulaşmaya çalıştığı tek bir soru vardır: İnsan birlikte yaşamak için ne yapmalıdır? Bu soruya yanıt olması bakımından iş, emek, eylem ve özgürlük kavramları da Arendt için ayrı bir öneme sahiptir ve insan tek başına yaşadığında bu kavramların ortaya çıkardığı durumları özsel olarak kavrayamaz.

Diğer yandan kamusal alana dair bir başka teorisyen de John Rawls'dır. Rawls'ın önemi, adalet temelli bir siyasal liberalizm anlayışının beraberinde, düşünce farklılıklarının birbirlerine engel olmadığı bir kamusal alan kuramı geliştirmiş olmasında yatar. Ona göre "kamusal siyasal tartışmalar, anayasal esaslar ve temel adalet meseleleri söz konusu olduğunda, her zaman ya da neredeyse her zaman, her bir vatandaş tarafından en makul kabul edilen makul liberal adalet anlayışlarının biri tarafından ortaya konan nedenler doğrultusunda makul olarak kararlaştırılabilmelidir" (Rawls, 2007, s.33). Rawls için modern özgürlükler, düşünce ve vicdan özgürlüğü, kişilerin belirli temel hakları, mülkiyet hakkı ile hukuk devleti olarak çerçevelenir (Rawls, 2007, s.50). Liberal "kamusal diyalog modeli" kavramı etrafında şekillendirilen bu ilkeler, aslında liberal hukuk devletini tarif etmektedir. Rawls birbirinden farklı "iyilik" anlayışlarına sahip vatandaşların bir toplum içerisinde nasıl ve hangi şartlarda ortaklıklar kurabileceklerini, nasıl bir arada hayatlarını sürdürebilecekleri üzerine düşünmektedir. Onun bu düşünce etkinliği sonucunda ulaştığ1 anahtar kavram, "hakkaniyet için adalet"tir (Rawls, 
2007, s.50-52). Liberal demokratik değerlerin, birey haklarıyla aynı ortak zeminde toplanması gerekliliğini savunan Rawls'ın adalet anlayışı, çoğulculuk, evrensel hakların eşit biçimde uygulanması gibi vb. özelliklere sahiptir.

Yine benzer bir liberal anlam dünyasını desteklemesi bakımından buradaki önemli bir diğer kavram da kamusal akıl'dır. Rawls kamusal akıl kavramıla, bireylerin kamusal alandaki temsiliyetleri yoluyla kamusal işlevler görmelerini anlatır. Buna göre bireyler, mevcut çıarları ve amaçlarını tanımlarken, aslında başka bireylerin de benzer çıkar ve amaçlara sahip olabileceklerini onaylarlar. Dolayısıyla bu, liberal özgürlüklerin yasal olarak garanti altına alınması anlamına da gelmektedir. Devlet de aslen bu özgürlükler için vardır, "yansızdır" ve kamu otoritesi bu sınırları koruyabildiği ölçüde, kamusal akıl aktif hâle gelerek toplumsal kurumlara işlerlik kazandırır (Rawls, 2007, s.50-52). Zira bu özgürlükler devam edebildiği sürece, bireyler kamusal hayatta ifadesini bulan siyasal değerler üzerinden kurulacak bir uzlaşmayı da sağlayabileceklerdir.

Bununla birlikte, kamusal alan tartışmaları söz konusu olduğunda Richard Sennett'in "kamusal insanın çöküşü" kavramlaştırmasından da bahsetmek gerekmektedir. Sennett, insanların aile ve yakın çevrelerindeki kamusal hayatın 19. yüzyıla kadar sıcak ilişkiler kurulan bir içerikte olduğunu söyler. Fakat yine aynı kamusal hayat, 19. yüzyıl ortalarından itibaren sanayi kapitalizminin gelişimine paralel olarak artık değişmeye başlamıştır. Zamanla mevcut toplumsallık yerini, insanlar nezdinde özel hayatın "daha önemli" görülmesine bırakmış; kamusal hayat, özel hayat açısından önemli olduğu ölçüde eğer görmeye başlamıştır. Böylece insanlar özel alanlarına çekilip, kamusal alanlardaki etkinliklerini azaltma eğilimine girince, bu alanı da öncelikle devlet ve egemen sınıflar doldurmuştur. Öncelikle kamusal alana devlet ve egemen sınıfların müdahalesini arttıran bu gelişme, kamu ile özel alan arasındaki sınırları da geri dönülmez biçimde silikleştirmiştir (Sennett, 2010, s.44-47). Modernitenin getirdiği yeni hayatın eleştirisini yapan Sennett'e göre, toplumsal ilişkilerin hızla değiştiği, güçlenen burjuva sınıfının güçlü ve etkin bir kamuoyu oluşturmaya başladığı bu dönemde kamusallık yavaş yavaş zemin kaybederken, bu gelişmeyi destekler biçimde aile yaşamında da bir takım değişimler gerçekleşmektedir: 
"Aile, toplumun saldı̆̆g dehşetten kaçışın bir sığınăğı haline geldikçe, adım adım büyük şehirlerdeki kamusal alana değer biçmek için kullanılan bir ahlâki kıstas haline geldi. Insanlar, aile ilişkilerini bir ölçüt olarak kullanarak, kamusal alanı, Aydınlanma çă̆ında olduğu gibi sınırlı bir toplumsal ilişkiler kümesi gibi görmek yerine, kamusal yaşamı ahlâki bakımdan sefil bir yaşam olarak görmeye başladılar. Mahremiyet ve istikrar ailede bütünleşmiş görünüyordu. Bu ideal düzen karşısında kamusal düzenin meşruluğu tartışma konusuydu" (Sennett, 2010, s.37).

Ne var ki "kamusal alana duyulan inancın korunması aileden ve aileye ilişkin kurallardan kaçmaya yönelik güçlü bir arzuyla bağlantılıdır" ve bu bağlantı, "mahrem toplumu" iki ilke temelinde kurar: Narsisizm ve gemeinschaft (cemaat)... (Sennett, 2010, s.286-287). Buna göre 19. yüzyılda kişiliğin kamusal alana girişi, bu iki ilkenin önünü açmıştır. Narsisizm kişilerin ne yaşarlarsa yaşasınlar her durumda kendisine odaklanmasıyla ifade edilecek bir gerçeklik olarak ortaya çıkarken; kamusal insanın yok olduğu zamanlarda kişilerin aileleri dışındakilerle açık, dolaysız ve duygusal ilişkiler yaşama amacının bir sonucudur. Burada bir samimiyet arayışı/beklentisi olsa da Sennett'e göre cemaatler kişileri kamusallıktan uzaklaştırmaktadır. Bu ve benzeri sebeplerle de modern dönemde kamusal insan çökmüştür.

Sonuç itibarıyla, kamusal alan teorilerini Habermas, Arendt, Rawls ve Sennett özelinde ele alsak da bu alana dair tüm yorumların hemen hemen benzediği ortak noktalar vardır. Zira kamusal alan, siyasetin meşrulaştırıldığı, politik iletişimin sağlandığı, politik bilgilere doğrudan ulaşılan, politik aktörlerin görünür olduğu ve sosyal sorunlara dair "söz söylenebilen" simgesel bir mekândır. Nihayetinde kişilerin varoluşuna dair bütün siyasal mücadelelerin hayatî meşruiyetini aldığı (/almaya çabaladığı) yaşam zemini, yine aynı kamusal alan içerisinde şekillenir. Böylelikle kamusal alan gerek klasik anlamiyla gerekse de zemin değiştirerek ulaştı̆ siyaset ve onun son dönemlerdeki gözde unsuru kimlik politikaları bağlamında yeni bir biçime bürünmüştür. Nitekim politik kimliklerin yeni gösteri mekânı, sosyal medya ağlarıdır ve burada yeni bir kamusal dil üretilmektedir. 


\section{Sosyal Bir Mekân Olarak Kimlik}

İnsanların dış dünyaya karşı sundukları en belirgin sosyal yönleri, onların kimlikleridir. Belli bir sosyallik içerisinde gerçekleşen insan eylemlerinde kimlik, kişilerin kültürel çevrelerinde tanınma ve yer edinme mücadelelerinin de bir parçasıdır. Üstelik hangi çeşidi olursa olsun kimlik, kültüreldir. Kültürel bir alanda doğar, şekillenir, değişir ve sunulur. Zira insan topluluklarının kültürel gerçeklikleri, kimliklerin kolektif yapılarının eseridir. Dolayısıyla bu ve benzeri etkenler, kimliğin belli bir oluşma süreci geçirdiğinin de kanıtı gibidir. Çünkü kimlik, kolektif olarak oluşan ve yine belli kolektif ortaklıkları bünyesinde taşıyan karşılıklılık esasına dayalı bir devamlılı̆̆ın adıdır. Hatta bu özelliğinden dolayı "kolektif kimlik, belirli bir durumu değil, bir süreci yansitır. Keza Nuri Bilgin'e göre "bir komünotenin kimliği, diğer komünotelerle ilişki içerisinde zamanla değişir. Hiçbir komünote tek başına ve zaman-mekân dışı bir tözsel kimliğe sahip değildir" (Bilgin,1994, s.53). Bu zaman-mekân dışıllk, kolektif kimliğin objektif olabildiği gibi duruma göre sübjektif özellikler de gösterebileceğinin delilidir. Diğer yandan Levi-Strauss da "kolektif kimliklerin, fark ve karşıtlık tarzında gözlendiğine, herkesin kendini, diğerinden farklı özgül bir bireysellik olarak sunduğuna" işaret ederken, farklılıkların kaynağının "karşı olma, ayırt edilme, kendisi olma arzusunda" yattığını söyler; böylece "kültürlerin ve kimliklerin çeşitliliği doğal bir olgu değildir; etnosantrizm hem ilkel hem de modern toplumlarda gözlenen çok yaygın bir tutumdur" ve "sağlam psikolojik temelleri vardir" (Levi-Strauss'tan aktaran Bilgin, 1194, s.54-55). Bu yönüyle de kimlik, belli bir insan topluluğunun kendileri hakkında bilinci ve duygularıyla ilgili anlamlar kümesidir.

Bununla birlikte kimlik kavramı pek çok farklı açıdan ele alınsa da bu makalede sözü edilecek kimlik türü, kişilerin sosyal medya ağlarında sergiledikleri politik kimlikleridir. Kişilerin günlük yaşantılarında kendilerini diğer kişilere sundukları kimlik türlerinden belki de en kullanışlı ve konforlusunun, yine politik kimlikler olduğu söylenebilir. Zira politik kimlik, kişilerin topluluk içerisinde nerede durduklarını başkaları nezdinde ayırt ettikleri sembolik bir gösterge, bir bağlılık ve ifade aracıdır. Genel itibarıyla meşru/yasal olmanın bir kriteri olabildiği gibi, kimilerini (azınlıklar, ötekileştirilenler, kadınlar vb.) meşruiyet dışına taşımanın da 
kolay görülen bir yoludur. Bu nedenle rasyonel temelleri daima tartışmalı olacak biçimde, bir takım topluluklarca duygusal olarak bağlanılan politik kimlikler çoğu kez, devlet, iktidar ya da muhalefet merkezli, türlü manipülasyonlara açı bir niteliğe de sahiptir. Buna göre politik eylem, tepki, düşünce ya da davranışlar, güncel siyasetin seyrine göre manipüle edilirken, burada sürekli olarak diri tutulmaya çalışılan politik kimliğin duygusallığa dönük sübjektif yönüdür.

Diğer yandan politik kimlik, topluluğa bağlılığa dayalı, ötekiler'i dışarıda bırakacak şekilde ortak bir "biz" duygusu taşıyan anlam, hafiza ve semboller deposudur. Çünkü politik kimlikler, topluluğun hafızasından ortak olarak beslenirler; hafıza içerisindeki önemli ya da daha az öneme sahip olduğu düşünülen pek çok olay, kişi, tarih, şehir, savaş, göç gibi vb. durumlar politik kimliğin kabulünde, olgunlaşmasında, sunumu veya başka kimliklerle olası çatışmalarda merkezî bir yere sahiptir. Dahası hafıza, benzer politik yaklaşımlara ait kişiler arasında kimliğin alt belleği şeklinde işlev görerek davranışları düzenler, aynılaştırır. Zaten "kolektif kimlik, bellek süreçlerine bağlıdır ve herhangi bir grubun üyeleri, kendilerini ortak geçmişlerin anılarına dayanarak tanımlarlar. Böylece toplumsal grupların sürekli bir oluşum içinde olabildikleri, sınırlarını sürekli olarak tanımladıkları görüşüne dayanan dinamik bir kimlik fikri" gelişir (Schlesinger'den aktaran Morley ve Robins, 1997, s.74). Aynı şekilde politik kimlikler, sembolik davranışlar ile kimliğin sembolik anlamlarıyla da doludur. Semboller burada, bir taraftan politik kimliklerin yaygınlığını sağlarken, diğer taraftan da içerdikleri anlam dünyalarıyla politikleşmiş kişileri, dil ve söylem bakımından beslerler. Zira her politik sembol bir zihniyet şekli, bir ideolojik tavırdır.

Aynı zemin üzerinden ilerlersek, Ernesto Laclau da her kimliğin inşasının temelinin "özdeşleşme" ye dayandığını söyler. Laclau'ya göre "herhangi bir toplumsal kimlik, boyutlarından biri olarak, basitçe tanımayı değil inşayı zorunlu olarak gerektirir. Bu inşa sürecini anlamada anahtar terim, herhangi bir kimliğin temelinde bir yoksunluk bulunduğu açık iddiasıyla psikoanalitik özdeşleşme kategorisidir" (Laclau, 1995, s.11). Burada esasen "özdeşleşilen", düzendir. Sahip olunan politik kimlik, ister etnik isterse de dinsel veya mezhepsel olsun, bir aidiyet üzerinden mevcut politik düzenle ve onun zihni evreniyle tek taraflı bir “özdeşleşme" sağlar. Hatta "özdeşleşme" etrafında düşünüldüğünde, 
"kültürel çeşitlilik ve türdeşlik, merkeziyetçi, standartlaştırıcı ve birlikçi güçler tarafından çevrilmiştir. Bu noktaya kadar bunun en gelişmiş biçimi ulusal-devlet olmuştur" (Morley ve Robins, 1997, s.115). Zira her ulus devletin kuruluş düşüncesi, etnisiteden referans alan bir politik kimliği inşa etme amacı taşır. Çünkü "çoğu millî-devlet çok etnili olmakla birlikte; başlangıçta pek çoğu, öteki etnileri veya etnik parçaları, adını ve kültürel karakterini verdiği bir devlete ilhak eden ya da cezp ederek çeken egemen bir etni etrafında oluşmuşlardır" (Smith, 1994, s.70). Üstelik "millet, bir etnide olduğu gibi, tanım gereği ortak mitleri ve anıları olan topluluktur. Ayn zamanda da teritoryal bir topluluktur... Etnilerin 'kendi' teritoryal memleketlerinde ikamet ediyor olmaları gerekmez. Ortak bir işbölümü ya da ekonomik birliktelik göstermeleri de gerekmez, çoğu durumda da göstermezler zaten" (Smith, 1994, s.70-71). Smith'in burada vurgulamak istediği asıl mesele, millî devlet ya da millî kimliğin kuruluşunun, egemen güçlerce düzenlenen ve kolektif bir süreç olduğudur. Dolayısıyla bu süreçte de millî devlet için "milleti var eden değerler", kurucu öğeler olarak, dil ve sembolizmdir (Smith, 1994, s.119).

$\mathrm{Bu}$ çalışmanın yöntemi olan "içerik analizi" açısından düşündüğümüzde ise, sosyal medyada politik kimliklerin sunumu esnasında geçen dil ve sembolizmlerin peşine düşmek, işlevseldir. Çünkü;

“...Dil aracılığıyla paylaşılmış olan sembolik ifadeler toplumsallaşma aracıdır ve aktörle topluluk arasındaki sosyal bağı yaratır... Semboller ancak kelimelerle tasvir edildiklerinde bize bir anlam ifade ederler. Dahası, sembolik olan eylemleri ve tüm nesneleri kelime kullanarak tanımlarız. Dolayısıyla bir tür anlatım öğesi olarak kelimeler, gerçekte bütün sembolleri mümkün kılan bir öneme sahiptir. O halde genel olarak kültürü, özel olarak da politik kültürü, esasen dilsel olarak organize edilmiş yorumsal örüntüler bütünü olarak yaşadığımızı ve bu yaşadıklarımızı kelimeler şeklinde anlatıp aktardığımızı söyleyebiliriz" (Sarıbay, 2000, s.77).

Burada, bir kavramlar dağarcığı olarak ele alınan dil ve söylemle ifade edilmek istenen durum, onların bir sosyal bağlama, bir anlam dünyası ile zihniyete tekabül etmesidir. Zihniyet, politik kimliklerde karşılığını bulan dil ve söylemlerin biriktiği yerdir; kültürel olan'dan (dinî, politik, inançsal, ideolojik, ahlâkî vb.) beslenir. Öyle ki insan, zihniyet açısından kendisini çerçeveleyen bu kültürel olan'ın hükmü altındadır ve onun 
vasıtasıyla inşa edilir. Üstelik insan öznesi, dil ve söylem süreçlerine dâhildir ve anlamlar söz konusu olduğunda belirleyiciliği de sınırlıdır. Nitekim insanlar çevresindeki kültürel süreçlerin etkisiyle bir kimlik edinirler. Bu sebeple de politik kimliklerin hem kurulmasında hem de sunumunda dil ve söylemlerin önemi büyüktür. Çünkü dil ve söylemler toplumsal katmanların her alanındaki kültürel, politik, dinsel, geleneksel vb.'leri faaliyetler içerisinde yaşarlar, bu yapılar içerisinde biçimlenirler. Zaten söylemin karmaşı analizi, metinsel analizle sınırlı değildir ve söylem analizinin karakterlerinden birisi de metin ve konuşmaları betimleyerek söylemin boyutlarını pek çok aşamada geliştirmesidir (Van Dijk, 1991, s.110-111).

Sonuç olarak zihniyet, dil veya söylem olsun, tümü birer metindir. Bu metinlerin içerisindeki kavram kümelerini ortaya çıkarabilmek, ucu sosyal, ekonomik, dinsel, ahlâkî, ideolojik vb. anlam dünyalarını da bir miktar aydınlatmak yerine geçecektir. Değişen kamusal alan anlayışı ile kamusallık algısını tespit edebilmek adına söylem analizini bu çalışmanın araştırma yöntemi olarak seçmek, sosyal medyadaki parçalı/belirsiz ilişkilerin anlamlandırılması; politik kimliğin nasıl yasallaştığı; tahakküm, güç ve iktidar ilişkilerinin nasıl kurulduğu; dinî ve etnik söylemin hangi kavramlar aracılığıyla meşrulaştırıldığı ya da egemen söylemlerin nasıl üretildiği gibi pek çok merakın peşine düşmek adına en uygun analiz yöntemi olduğu söylenebilir. Zira sıradan bir yorum bile, bir zihniyet şeklinin açığa çıkmasına yol açabilir ve sosyal gerçeklikler, kolektif kimlik, zihniyet ve pratiklerin yansıması olan dil ve söylemlerde gizlenir. Dil ve söylemler, anlama yaklaşmanın anahtarlarıdır.

\section{Yeni Kamusallığın Mekânı Olarak Sosyal Medyada Politik Kim- liklerin Sunumu}

Günlük hayat içerisinde teknoloji kullanımının giderek arttığ1 ve internetin (özellikle gençler arasında) neredeyse temel bir ihtiyaca dönüştügüü, günümüzün tartışılmaz bir gerçekliği olarak artık önümüzde durmakta. Öyle ki, bilgi teknolojilerindeki gelişmeler bu hızla devam ettiği sürece internetin sağladığı olanakların önemi daha da artacak gibi görünüyor. Bununla birlikte internet sisteminin 2000'lerin ilk yıllarından itibaren insan hayatına kattığı yeni ve etkin bir iletişim aracı olarak sosyal medyanın 
artık insan yaşamının tam merkezine yerleştiği de söylenebilir. Dahası yaşadığımız zamanı düşündüğümüzde, kişilerin birbirinden çok farklı talep, beklenti, amaç ya da isteklerine karşıllk verebildiği düşünülen sosyal medya ortamları, bireysel benliklerin sunulduğu biricik yerler haline geldi. Buna göre, genel bir tanım etrafında ele almak gerekirse sosyal medya:

"Sürekli güncellenebilmesi, çoklu kullanıma açık olması, sanal paylaşıma olanak tanıması vb. açısından en ideal mecralardan biri olarak kendini göstermektedir. Insanlar sosyal medyada günlük düşüncelerini yazmakta, bu düşünceler üzerine tartışabilmekte ve yeni fikirler ortaya koyabilmektedirler. Ayrica kişisel bilgilerinin yanında çeşitli fotoğraflar, videolar paylaşabilmekte, iş arayabilmekte ve hatta bulabilmekte, ayrica sıkılmadan gerçek dünyayı sanal ortamda yaşayabilmektedirler. Bu durum gün geçtikçe tüm dikkatlerin bu alana yönelmesine sebep olmakta ve yenilenen sanal dünyaya yeni bir kavramsal çerçeve çizmektedir" (Vural ve Bat, 2010, s.3349).

Yine de bu makalenin ilgi merkezi itibarıla internet sistemi içerisindeki farklı sosyal medya ortamlarındaki paylaşımların, kamusal alan, kamusallık ve kimlik kavramlarıyla ilişkisi burada tartışılmaya muhtaç olarak önümüzde durmaktadır. Çünkü sosyal medyanın içerisinde yer aldığı "internetin, Habermas ve takipçilerinin anladığı şekliyle ideal bir kamusal alanın yapıtaşı olan rasyonel müzakereyi destekleyip desteklemediği; farklı kamusal alanların varlığına ve farklı grupların seslerini duyurmalarına izin verip vermediği; çevrimiçi tartışmaların bir kargaşa m1 doğurduğu yoksa demokrasi kültürünü derinleştirip güçlendirdiği ve internetin devrimci potansiyelinin kitlesel ticari kültür tarafından soğrulup soğrulamayacağı, cevaplanmayı bekleyen soruların başında gelmektedir" (Özçetin, Arslan ve Binark, 2012, s. 52). Burada her türlü kişisel paylaşımların yapıldığı sosyal ağların düşünsel anlamda insanları birbirlerine ne kadar yaklaştırdığı, hangi noktalarda ve ne derece uzlaştırıp demokratik anlayışın gelişimine katkı sağladığı, hâlâ süren bir tartışmanın temasıdır. Hâlbuki anayasal demokratik düzenin tesisinde medyanın üstlendiği roller düşünüldüğünde, politik topluluğun devlet karşısındaki pozisyonu iletişim özgürlüğü etrafında düğümlenir. Hatta Frankfurt Okulu'nun "kültür endüstrisi kuramı" ve kitle iletişim 
araçlarının işlevlerine dair söylediklerinden beridir teknoloji, iletişim araçları, devlet, ideoloji, totalitarizm, demokrasi gibi başlıklar arasındaki ilişkinin sosyal bilimcilerin ilgi odağı olduğu da bir başka gerçeklik biçiminde buraya eklenebilir. Dolayısıyla özgürlükler, sivillik, demokrasi vb. kavramların önemi, ayn yoğunlukla günümüzde de internet ve sosyal medya üzerinden sürdürülen düşünsel uğraşların temel meselesi olmaya devam etmektedir.

Zira sosyal medya başta olmak üzere tüm internet ortamları, bir yönüyle fikirlerin oluşma ve paylaşım imkânı bulduğu, paylaşılırken çarpıştığı, müzakere edildiği, birbirlerinin farkına vardığ veya sosyal problemlerini dillendirme ile aktif biçimde seslerini duyurabilme fırsatlarını yakaladıkları demokratik mekânlar olarak görülürken; diğer taraftan da kitle üzerinde politik ve ideolojik algı oyunları ile yalan yanlış her türlü dezenformasyonun yapılabildiği; teknolojik üretimin lider devletleri nezdinde bazı ülkelerin, hatta kişilerin denetim ve kontrollerinin rahatlıkla sağlandığı; demokratik ilkeleri, uzlaşmayı, karşısındakileri tanımayı geliştirmekten çok çatışma, nefret ve şiddet eğilimlerini güçlendiren bir araç şeklinde de tarif edilebilir. Aslına bakılırsa, nihayetinde internet ve sosyal medya ağları, her iki yaklaşımı da haklı çıkaracak pek çok niteliğe de sahiptir.

Bununla birlikte bir internet ortamı olarak sosyal medya, kişilerin politik kimliklerinin de karşı karşıya geldiği yeni bir kamusal mekândır. Nitekim kamu, "herkese açı, bütün topluma ait, özel ya da kişisel olmayan, aile ya da piyasa olmayan, kolektivizm, kolektif mülkiyet ve dayanışma, kamusal eylemlilik alanı, halk (insan grubu), kamusal alanlar (mekân, yer), kamusal hizmet (kurumlar) ve vatandaşlık hakkı ya da sorumluluğu ve temsil alanı olarak kavramsallaştırılmaktadır" (Durmuş, 2012, s.34). Hatta Rasmussen'e göre, “televizyon, radyo ve yazılı basın, daha merkeziyetçi ve bilgi gönderen ile bilgi alanın pozisyonlarının daha belirgin olduğu araçlardır. Bu kurucu nitelik üzerinde şekillenen kitle iletişimi aktif ve katılımcı bir kamusal alan yaratma konusunda kısıtlı imkânlara sahiptir. Oysa yeni medya, bu kurucu nitelikten azade oluşuyla, bireylerin aktif katılımı için daha açık bir alternatif yaratmaktadır" (Rasmussen'den aktaranlar Özçetin, Arslan ve Binark, 2012, s.54). Dolayısıyla internet ağları üzerindeki toplumsal mekânlar, sosyal medyanın giderek artan yoğunlukta ve kitlesel anlamda, söz söyleme ve problemleri tartışma, 
müzakere ve söylemsel etki alanı hâline gelmesi Habermasçı; birbirlerine üstünlük kurmak, uyum içinde hareket etmek, itibar görmek, konuşmak, ikna etmek gibi vb. eylemler için bir araya gelme bakımından Arendtçi; yurttaşlar açısından "en makul görülen" kamusal diyalog ortamı olması ve sonucunda özgürlükçü kamusal bir akıl ortaya çıkma ihtimali açısından Rawlsçı; mahremiyetin sergilenmesi ve aynı mahrem ve sıcak ilişkilerin olası çöküşü üzerinden de Sennettçi kamusal alan teorilerine karşılık gelebilir.

\section{Yöntem}

Nitekim aynı "karşılık gelme" hâlinin, bir kamusal mekân olarak sosyal medya ve onun yoğun biçimde kullanılan sosyal ağlarından birisi olan Twitter üzerinde yapılan paylaşımlardaki politik kimlik sunumları için de geçerli olduğu söylenebilir ve bu çalışmanın amacı, benzer bir gereklilik üzerine bu sunumların anlamlandırılmasına yönelik olacaktır. Buna göre, politik kimliğin bu sosyal ortamlardaki sunumlarının anlamlı kılınması adına seçilen araştırma tekniği de "içerik analizi" olmak zorundadır. Zira içerik analizi, "çok çeşitli söylemlere (discours) uygulanan bir takım metodolojik araç ve tekniklerin" bütündür ve bunlar, bir söylemi anlamada ve yorumlamada, mesajda gözlenen ve betimlenen öğelerden hareketle "kontrollü bir yorum ve genelde tümdengelime dayalı bir okuma çabası olarak nitelendirilirler" (Bilgin, 2000, s.1). Çünkü içerik analizi, kişilerin farkında olmadan etkilendikleri politik ve zihnî süreçlerin, iletişim esnasında ortaya çıkan metinler arasında gizlenen içerik ve yorumların belirlenmesi açısından yeni bir okuma olarak da değerlendirilebilir. Üstelik iletişim araçları vasıtasıyla gerçekleşen tüm iletişim süreçleri de bu analiz tekniğinin uygulama alanına girmektedir. Bu teknikle seçilen kavramlar kitap, dergi, sinema filmi, TV programları, sosyal medya mekânları vb. ortamlarda elektronik olarak taratılmakta ve kavramların hangi bağlamlara denk geldiği, hangi zihniyet biçimlerini yansıttıkları tespit edilmeye çalışılmaktadır. Zira bu özelliklerinden dolayı içerik analizi yönteminin Twitter'da sergilenen politik kimliklerin yorumlanmasında kullanılabilecek en işlevsel araştırma yöntemi olduğu da görülmektedir. 
Yine de içerik analizi yöntemiyle bir olguyu ele alırken, elde edilen verilerin azlık-çokluk gibi sayısal özellikleri bazen anlamını yitirebilir. Bazen tek bir örnek bile, bütünün gölgesi tekilde ortaya çıttı̆g için, içerik analizi yoluyla iyi bir zihniyet çözümlemesine değerli katkılar sağlayabilir. İlâve olarak böylesi bir çalışma, bir sosyal medya mekânı olarak Twitter'daki kullanıcı profillerinin niteliğine dair özelliklere de (yaş, meslek, eğitim seviyesi, hesap sahiplerinin "gerçek şahsiyetler" olup olmadığı vb.) odaklanmayacaktır. Neticede yazılan her twit'in arkasında bir politik şahsiyet, öğrenilmiş bir politik düşünce şekli vardır ve yazılan her metin de bir zihniyet biçimine karşılık gelmektedir. Dahası binlerce paylaşım arasından makaleye veri olarak alınan twit'ler, çalışmanın içeriğine en uygun ve çalışma için işlevsel olmalarına bakılarak ince bir seçime tabi tutulacaktır. Keza her paylaşımı çalışmaya taşımak, anlamı dağıtıp, parçalayabilir.

Diğer yandan her politik kimlik, bir anlam dünyasına, bir zihniyete ve söyleme karşılık gelir. Dolayısıyla bu çalışma, öncelikle veri olarak politik kimliklere ve bir kamusal alan olarak sosyal medyada kimliklerin barındırdığı söylemlere dayanmak mecburiyetini taşır. Bu mecburiyet de bizleri, veri olarak seçilen politik kimliklere dair söylemlerin geçtiği konu alanımız olan Twitter ve onun tarama modülüne ulaştıracaktır. Sonrasında ise Türkiye' de yaygın politik düşünceler olarak geniş anlamda kabul gören, "İslâmcılık", "Müslümanlık", "solculuk", "sosyalizm”, “Türkçülük" ve "milliyetçilik" kelimeleri bu modül üzerinden taratılıp, tarama sonucunda çalışmaya katkı sunabileceği düşünülen twit'lerin ekran görüntüleri alınacaktır. Yine de burada dikkat edilmesi gereken şey, sosyal medyadaki kişiler her ne kadar kendilerini bir politik düşünce aracılığıyla ifade etseler bile sonuçta bu durumun kimliksel bir karşılığının olduğu gerçekliğidir. Bu gerçeklik sonucunda aynı politik düşünce ekollerinin kimliksel yansımaları olarak "İslâmcı", "Müslüman", "solcu", "sosyalist", "Türkçü" ve "milliyetçi" kelimeleri de benzer yöntemle yan yana taratılacaktır. Bununla birlikte kamusal talepler olan "demokrasi", “hürriyet/özgürlük", "hak/haklar", "inanç", “özel hayat”, "mülkiyet", "güvenlik", "adalet", "kanun”, “Anayasa" gibi kavramlar da yukarıdaki politik düşünce ve kimliklerle çaprazlama eşleştirilip aranacaktır. Böylece bu twit'lerde geçen söylemler tasnif edilerek seçilen politik kimliklerin kamusal bir mekân olan sosyal medyada nasıl ve hangi 
bağlamlarla birlikte sunulduğunun, farklı uçlardaki politik kimliklerin kamusal haklar söz konusu olduğunda ne gibi noktalarda ortaklıklaştıkları ya da ayrıldıklarının peşine düşülecektir. Dahası veri olarak alınan twit'lerin hesap sahiplerinin adları makalede gösterilmeyecektir. Zaten aynı arama modülüne ilgili metin girilerek twit sahibi (eğer yazdıklarını silmediyse) rahatlıkla bulunabilir. Seçilen twit'lerin ekran görüntülerinin ise "son not" şeklinde numaralandırılarak makalenin sonunda yer alması uygun bulunmuştur.

\section{5a. Twitter'da Politik Kimliklerin Tanıtımı ve Çerçevesi}

Bir politik kimlik, esasen o kimliğin taşıyıcısı kişiler için bir ifade aracıdır. Politik kimliğin pek çok unsuru (kültür, zihniyet, söylemler ya da semboller gibi), bir açıdan da insanların birbirleriyle olan iletişimlerinde kendi politik konumlarını karşılarındakilere anlatmak için kullandıkları göstergelerdir. Öyle ki kişiler böylesi anlatımları yaparken bağlı bulundukları politik kimliği diğerlerine (yazılanları okuyan takipçiler ya da başkaları) mevcut sınırlılıklar içerisinde özetleyip, tanımını yaparak çerçeveledikleri de görülmektedir. Yine analiz alanımız olan sosyal medya ortamı Twitter'da da bunun izlerine rastlamak mümkündür. Sırasıyla gitmek gerekirse, örneğin farklı kullanıcıların binlerce twit arasından seçilen İslâmcılık düşüncesine dair kimliksel sunumları şu şekilde sıralanabilir: “İslâm'ın itikâdiyâtını, ahlâkiyatını, içtimâiyâtını, siyâsiyâtını daima zamanın ve muhitin ihtiyâciyâtına en muvafık bir surette tevsîr ederek bunlara gereği gibi tevfîk-i hareket etmekten ibarettir."(1) "İslâmcılık, Batı'ya meydan okumaktır."(2) "İslâmcılık, İslâm değildir ama onun bir ürünüdür. Bir İslâm teokrasisidir."(3) "İslâmcllık ve İslâm, Müslüman'ın kötülüğe karşı durma sorumluluğunu yerine getirmesi ve insanların Allah ile bağlarını koparmaya çalışan güçlere karşı mücadelesidir."(4) “Ahlaken Müslümanlaşamayanların siyaseten İslâmcılık yapmaları en çok İslâm'a zarar verir."(5) "İslâmcılık diye bir şey yoktur. Bir Allah bir Kur'an ve bir İslâm vardır... Uydurulma terimlerle ve içerikle işimiz olmaz."(6) "İslâmcılık modernist bir kafayla pozitivist bir zihniyetle İslâm'ı yorumlamaktır. İnanmaktan öte yorumlamak."(7) Örnekler fazlasıyla çoğaltılabilse de (buraya eklenmeyen çok daha fazla twit'in de bilgisiyle) öyle görünüyor ki, İslâmcılık bir yandan "meydan 
okumak" için bir araç olarak kabul görürken, diğer yandan da "bir uydurma", "modernist bir yorum" şeklinde tarif edilmektedir. Hatta diğer politik kimlik tanımlamalarının hiçbirisinde böylesi bir kabul-red ikilemine rastlamanın mümkün olmadığı da buraya eklenmelidir. Sadece İslâmcılık/İslâmcı kavramı söz konusu olduğunda böylesi bir ikiliğe rastlandı. Bunun sebebinin de Müslüman kimliğine dışarıdan iliştirilmeye çalışıldığı düşünülen "İslâmcılık" ve "İslâmcı" kavramlarına karşı çoktandır var olan bir tepkiye dayandığı söylenebilir. Öte yandan, bazı kullanıcılarca kabul gören biçimiyle de İslâmcılık, (Batı'ya, emperyalizme vb.) bir karşı duruş, bir mücadele, gelenek ve tutarlılık şekli olarak da algilanmaktadır.

Yine aynı minvalde, Müslümanlık/Müslüman üzerinden yürüyen anlatılarda da aynı kabule yönelik benzer tariflere rastlamak mümkündür: "İslâm/Müslümanlık, 'açık büfe' bir inanç değildir. İşine geleni alasın, işine gelmeyeni/canının istemediğini almamak/inanmamak gibi. Müslümanlar İslâm dininin bütününe (Kur'an'ın bütün emirlerine/öğütlerine) uymakla mükelleftir."(8) “Müslüman için iman, hayattır, candır. İman, Müslüman'ın damarlarında kesintisiz dolaşan kandır. İman olmayınca Müslümanlık iddiası tümden yalandır."(9) “Bilinçsiz Müslümanlık =düşüncesiz, cahil ve pasif iyi aktif kötü insana eşittir."(10) "Müslümanlık, hoşgörüdür, affetmedir. Müslümanlık, kulu sevmektir."(11) "Müslüman, Müslüman'ın kardeşidir. Ona zulmetmez. Onu düşmanına teslim etmez."(12) "Başta kendimizi sorgulayalım. İslâm ve Müslümanlık çocuk oyuncağı değildir. 'Mış' gibi yapmak hiç değildir. İşimize gelince Müslüman gelmeyince 'gavur' olma ihtimalimiz var mı yok mu?"(13) “Müslümanlık, parayla, namla, şanla olmaz. Müslümanlık, Allah'ın şeriatına yani emirlerine uymakla, yaşamakla olur."(14) "Müslüman, doğruya doğru; yanlışa, yanlış diyebilmelidir."(15) "Hepimiz milliyetçiyiz. Lakin asla milliyetçiliğimiz Müslüman oluşumuzun önüne geçmesin! Aksi halde helâk olmak kaçınılmazdır. Mühim olan Müslümanlık çatısı altında toplanabilmektir."(16) "Müslümanlık, dilde olmaz. Ezbercilikte olmaz. Önce insan olmayı öğreneceksin."(17) “Doğruluk Müslüman'ın şiarıdır, Müslümanlık göstergesidir. Yalancılık ise münafığın şiarıdır, nifak göstergesidir. Bu yüzden Müslüman asla yalan söylemez, yalana prim vermez, yalan yere yemin etmez ve yalanc1 şahitlik yapmaz."(18) " 'İslâmcılık iflas etti' demek, bu İslâm anlayışı ve 
bu Müslümanlarla iflas etti demektir. Yoksa yeni bir İslâm tasavvuruyla ve yeni bir Müslümanlık anlayışıyla yeniden deneme yapmak her zaman mümkündür ve yapılmalıdır. Ancak bu defa Müslüman olmayanları da kuşatacak şekilde olmalıdır." (19) Açıkçası bu ve benzeri twit'lerdeki kimliksel tarif, Müslümanlığı dinî bir inanç etrafında kümelerken, Müslüman'ın da neler yapması ve nasıl olması gerektiğinin anlatımlarıyla doludur. Bu sebeple, buradaki kimlik tariflerinde genel itibarıla inanç ve ahlâk üzerine yoğunlaşan, bu iki kavramı başlangıç noktası sayan bir ilgi de seçilebilir. Örneğin, doğruluk, yalan söylememe, nefsine hâkim olma ya da imanı şart koşma gibi... Yine de bu, mevcut kimliğe dair eleştirilerin olmadığ 1 anlamına da gelmemektedir. Zira içeriden gelen eleştirilerin çoğunun da "daha iyi mümin" olmaya, inancı ve imanı kuvvetlendirmeye yönelik mesajlar taşıdığı açık biçimde görülebilir. Lâkin Müslümanlık/Müslümanlar'a ilişkin en sert eleştirilerin neredeyse tamamının, Türkiye'nin sıcak politikasında olan bitenler ile Dünya'nın Müslüman coğrafyalarında yaşananlar üzerinden diğer politik kimlik sahiplerince yapıldığı da bir başka gerçekliktir. Hatta bu gerçekliğin, farklı politik kimlikteki kullanıcıların (örneğin sosyalistler, milliyetçiler gibi) eleştirilerinin ortak çıkış noktası olduğu da belirtilmelidir.

Diğer taraftan, bir başka politik kimlik olan solculuk/solcu anlatımı etrafında da pek çok tartışmanın geçtiği görülmektedir. Hatta taranan twit'ler itibarıyla üzerinde en çok tartışma ve spekülasyon yapılan politik kimliğin bu olduğunu söylemek de yanlış olmayacaktır. Seçilen bazı yorumları sıralamak gerekirse: “Solculuk, kapitalist düzene karşı olan, zenginliğin eşit dağıtılmasını isteyen, siyasal ekonomik alanda kökten değişiklik amaçlayan bir akımdır."(20) "Sağcı veya solcu olmak suç değil ideolojidir yaşam biçimidir. Şayet aşırıya kaçarsan aşırı solcu faşist olur, aşırı sağcı da ırkçı olur."(21) "Türkçülük üzerinden kurulan solculuk kimseye fayda sağlamaz." (22) "Türkiye'de dünyada olduğu manada bir solculuk neredeyse yok. Bütün dünyada işçiler, ezilenler solcu iken Türkiye' de burjuvalar solcu olmuş."(23) "Komünistlik de solculuk da emperyalistlerin kullanışlı piyonlarıdır."(24) “Devrimcilik sola yakındır desek yanlış olur, solculuk devrimciliğe yakındır. O yüzden içinde insanlığ 1 yaşatan ve onun için mücadele eden herkesin kendini solcu gibi hissetmesi ondandır."(25) "Devrimcilik solculuk değildir... Her solcu devrimcidir diyebiliriz ama her devrimci solcu değildir."(26) Yine buraya 
eklenemeyen pek çok twit'te de solculuk/solcuya dair genel ifadelere denk gelinse de kullanıcıların temel derdinin politik kimliğin "ne olduğunu" anlatmaktan çok, "ne olmadığından" bahsetmek olduğu görülebilir. Yine aynı anlatılarda, bu politik kimliği sıklıkla dünyadaki diğer "solculuk" örnekleriyle karşılaştırılmaya yönelik bir çabaya da rastlanmıştır. Tabi bu çabanın tamamen öznel, Twitter profillerinin yerel motiflerle dolu ve kendi anladığı ya da içerisine sığmaya çalıştığı bir kimlik tanımı olduğu da söylenebilir.

Bununla birlikte Twitter'da, sosyalistlik/sosyalist kimliğiyle ilgili de aynı "gerçeklik-sahtelik" tartışmalarının, bir kademe daha düşük oranda olsa da, yaşandığı görülmektedir: "Sosyalistlik, sözel zihinsel bir eyleme alanı değil, yaşamın tüm alanlarını kapsayan sınıfsal ve kişisel bir duruştur, seçilmiş ve yaşama geçirilmiş bir kimliktir. Bu açıdan bakılınca bilinen sosyalistlerin hiçbiri gerçek sosyalist değildir. Çoğu iyi niyetli lümpenlerdir."(27) “Demokratlık ve sosyalistlik, birbirini tamamlayan ilkelerdir; demokrat olunmadan sosyalist ve sosyalist olmadan da demokrat olunmaz."(28) "Sosyalistlik diye bir şey yoktur. Anarşi peşinde koşan, din imanla alakası olmayan şiddetle beslenen kişidir sosyalist. Eşitlik kardeşlik hikâye."(29) "Türkiyemde sosyalist komünistlik dinsizlik veya imansızlık demek değildir; sosyalistlik komünistlik hakça bölüşüm hakça adalet demektir."(30) "Tek taraflı sosyalistlik olmaz. Sosyalist olaylara adalet çevresinden bakar."(31) Görüldüğü gibi, kullanıcılar genelde sosyalizmin bazı temel kavramları (eşitlik, kardeşlik, evrensellik, barış vb.) üzerinden bir anlatı geliştirse de bu söylem ne sosyalistliğin ne de ona ait olduğu düşünülen değerlerin açıklamasına yönelik değildir. Sosyalist kimliği karşısındakiler, bunu olumsuz olduğunu düşündükleri bazı durumlarla (anarşizm, dinsizlik vb.) birleştirme çabası içindeyken, sosyalist kimliği sahiplenenlerin de böylesi iddiaları boşa çıkarma gayreti içerisinde oldukları seçilebilir.

Diğer taraftan Türkçülük ve Türkçü politik kimliklere geldiğimizde daha zengin bir anlatıyla karşılaşıyoruz. Burada tema artık bir kimlik savunusundan çıkıp, doğuştan getirilen özelliklerle iktidar talebinde bulunan bir anlatıya dönüşür. Öyle ki, "Türkçülük bir ülkü, siyaset ise iktidara geçme taktiğidir. Bu sebeple bir ana inanç ve ana düşünce olan ülkü asla değişmediği halde siyaset yani taktik her zaman değişir."(32) “Türkçülük kötü bir şey değil, ırkçllık kötü bir şeydir."(33) “Bir gün 
ülkede milliyetçi geçinen politikacılar, yöneticiler, sanatçılar, aydınlar hiçbir çıkar kaygısına düşmeden, yiğitçe, korkusuzca Türkçü söylemlerde, Türkçü tavırlarla milletin karşısına çıkarlarsa o gün Türkçülük büyük bir utkuya ulaşır." (34) “Türklük ülküsü bizden amansız bir görev ahlâkı istiyor. Her Türkçü bulunduğu yerin görevini inançla yaparsa, Türkçülük ülküsü sağlamlaşır. Türklük güçlenir."(35) “Türkçülük genel yapısı itibarıyla kandaştır. Türkçülük fikre dayanır. Türkçü, Türk'ten başka dostu olmadığını bilir."(36) "Sevmek Türkçü bir eylemdir. Türkçülük ayrımcılık değil seçiciliktir. Kalite, seviye, kıymet aramaktır... Her insanı bir tutmamak, sevilmeye lâyık olanı kayırmaktır."(37) "Bizim Türkçü olmamız, bozkurt işareti yapmamız, herhangi bir siyasi partiye mensup olduğumuz anlamına gelmez. Türkçülük siyaset üstü bir fikirdir."(38) "Türkçülük kimsenin dini inancını sorgulamaz, her inanca aynı mesafede durur. Bunu yapmıyorsan zaten Türkçü olamazsın."(39) “... Bizim için Türkçülük, bir kan meselesi olduğu kadar bir vicdan ve kültür meselesidir. Türkçüyüz ve her vakit bu istikamette çalışacağız."(40) "Herkes milliyetçi olabilir. Milliyetçiliğin anlamı millet ve vatan sevgisidir. Herhangi bir ölçütü yoktur. Tahsil birikim ve kültürel altyapı aranmaz. Türkçülük ise bir alt şıktır. Bir milliyetçi, Türkçü olmak zorunda değildir, ancak bir Türkçü milliyetçi olmak zorundadır."(41) "Türkçülük kimsenin dini inancını sorgulamaz, sormaz, yargılamaz. Önemli olan soy birliğidir, kan kardeşliğidir. Türk töresini özümsemek, Türklük bilincine ulaşmaktır. İnsanların inançlarıyla uğraşmak, hor görmek ya da tavır almak, Türkçülük ülküsüne sadece zarar verir."(42) Açıkçası diğer politik kimlik sunumlarında çok seyrek rastlanan bir durum Türkçülük ve Türkçü kimlik anlatılarında karşımıza çıkmaktadır. Bu, politik kimliğin bir kimliksel tanımlama olmaktan çıkıp, bir amaç etrafında bir misyon, görev, ülkü ve ulaşılması gereken fikirler üstü bir mertebe pozisyonuna yükseltilmesidir. Burada tek ölçüt, "Türk olmak" ile "Türkçülük bilincine sahip" bulunmakla sınırlandırılmıştır. Politik kimlik anlatısı, benimseyenlere bir hedef ve istikamet belirlediği için de gücünü duygusal bağlllıklardan (soy/kan aracılığıyla sağlanan kardeşlik gibi) alır. Yine belirgin biçimde görülmektedir ki, bu politik kimlik mensuplarından bazıları İslâmcılık ve Müslümanlık kimliklerinin din üzerinden yaptıkları ayrımları, "doğru" bulmamaktadır. Burada alıntı yaptığımıza benzer pek çok twit, 
temel ayrım noktasının "din" değil, bir "seçicilik" mertebesi görülen "Türklük" olması gerektiğini iddia etmektedir. Burada din aracılığıyla yapılan ayrım genel kabul görmezken, soy/kan vasıtasıyla yapılan ayrım "töre" ye ait sayılmaktadır.

Son olarak, milliyetçilik ve milliyetçi politik kimliklerinin Twitter'da hangi söylemlerle sunulduğuna bakacak olursak, yine mevcut siyaseti yönlendirmeye dönük çabalarla karşılaştığımız söylenebilir. “Türk milliyetçiliğinin temelini, ülke sevgisi oluşturur, (Bu ülke tam bağımsız ve dili Türkçedir), siyasi partiyle milliyetçilik olmaz ve bu ülkede her siyasi hareket milliyetçi olmak zorundadır, değilse bu ülkeye ait değildir. Bu ülkeye ait olmayan gereksizdir."(43) "Amerikan güdümlü milliyetçilik ancak uşaklığı kuvvetlendirir. Milliyetçilik her şeyden önce bağımsızlıktır, bağımsız karar alma yeteneğine sahip olmaktır. Milliyetçi, akıllı olmak zorundadır."(44) "Vatan, bayrak milliyetçilik olmadan olmaz! Atatürk milliyetçi olduğu için kazanmıştır." (45) "Milliyetçilik, hem sosyal hem kültürel hem ekonomik hem politik ve hem de askeri cephesiyle bir bütündür. Milliyetçi, her sahada milliyetçidir."(46) "Irkçılık ve milliyetçilik birbirinden çok ince bir çizgi ile ayrılır. O çizgi de başka milletlere zarar vermeye başlayınca ırkçı olursun. Başka milletlere saygın olduğu zaman da milliyetçi."(47) "Milliyetçilik, millet ve vatan sevgisi ise anti emperyalist olur. Ümmetçiden milliyetçi olmaz, olamaz."(48) "Atatürkçü olmayan Türk milliyetçisi olamaz. Onlar kendilerini milliyetçi diye adlandıran, siyasi İslâm'a hizmet eden sentezcilerdir. Bugün milliyetçilik görüşünün temellerinin tek oturduğu kesim Türkçülerdir. Her kesimin milliyetçiliği farklıdır derseniz aynı yolda olamayız."(49) "Milliyetçilik, şekilcilik değildir. Milliyetçiyim diye geçinen bazıları şekil milliyetçisidir. Milletin sorunları, yaşam kalitesinin yükseltilmesi, üretime katkı, dışa bağımlı olmama gibi hiçbir şeye değinmeden vatan, bayrak edebiyatı yapan şekilciler görünüşte milliyetçi, aslen gericidir."(50) "Milliyetçilik belirli bir zekâ seviyesi ister. Özellikle Türk olup milliyetçi olmayan insan, aptaldır."(51) "Genç nesillerini milliyetçi olarak yetiştiren milletler, geleceğe güvenle bakabilirler. Milliyetçilik; mensubu olduğu milleti ilerletmek, yükseltmek, milli değerleri korumak ve geliştirmek duygusu ve şuurudur."(52) Burada özellikle belirtilmelidir ki, diğer tüm politik kimlik anlatılarının aksine milliyetçilik ve milliyetçi kavramlarına dair söylemlerin daha fazla açıklama ve tanım içerdiği görülmektedir. Bu yüzden, 
öteki kimlik sunumlarından farklı olarak bu kimlikle ilgili belirli bir sınır çizme çabası da dikkate değerdir. Yine Türkçülük kimliğinde olduğu gibi, milliyetçi kimlik algısında da bilhassa İslamcılık kimliğiyle sınır çizmeye çalışma ihtiyacı seçilebilse de, asıl önemli olanın kimliği türlü suçlamalardan (ırkçılık gibi) kurtarmak ve gerçek milliyetçiliğin "ne olduğunu" anlatmak gayretinin ön plâna çıtığı söylenebilir.

\section{5b. Politik Kimliklerin Kamusal Taleplerle İlişkisi}

Kamusal talepler, insanların günlük yaşantılarında doğrudan istekte bulundukları pek çok ihtiyaca karşılık gelir. Yeni kamusal mekân olarak sosyal medya ortamları da artık bu taleplerin en ne ve hızlı iletildiği yerler haline dönüşmüştür. $\mathrm{Bu}$ bölümde, çalışma çerçevemiz itibarıyla seçtiğimiz politik kimlikler ile kamusal talepler ilişkisine bakılacaktır. İlk kamusal hakların talebine dair ilk kavramımız olan özgürlük, politik kimliklerle şu biçimlerde sunulmaktadır: "Adalet, özgürlük, nezaket, merhamet önerisi olmayan bir İslâmcllık içine çöker, çöküyor."(53) "Tarihte İslâmcılık ile onur, bağımsızlık, özgürlük gibi kavramlar yan yana alınmaz."(54) "Ateistlik, sosyalistlik, komünistlik istemek özgürlükse, neden Şeriat istemek de özgürlük değildir?"(55) "Müslümanlık reform edilmeli, insanlığın geleceği için kadına özgürlük sağlanmalı."(56) "Din bir seçimdir, İslâmiyet zaten özgürlük dinidir, dayatma değil."(57) "İslâmcılar'ın özgürlük anlayışlarının, sadece İslâmcılık özgürlüğünden ibaret olması sorunsalı..."(58) "Sağcllık veya solculuk mevzusu değildir. Sorun, özgürlük ve temel hak sorunudur."(59) "Solculuk 'eşitlik, adalet, özgürlük, hoşgörü' gibi İslâmiyet'in temel kavramlarını savunur. Müslümanlar sol düşünceye inanmalıdır. İslâm, sol tandanslı bir dindir."(60) "Savaşmak değil de belli bir yaşam alanında özgürlük tanımak gerek. Sosyalistlik budur."(61) "Sosyalizm dinsizlik değildir... Sosyalizm hoşgörüdür. İnanca sayg1, düşünceye özgürlük."(62) “Türk'ün simgesi Bozkurt'tur. Çünkü özgürlük kutludur."(63) "Milliyetçilik, ezilen uluslar için bir özgürlük ideolojisidir."(64) Burada dikkat çeken durum, kavramın anlatısının çoğunlukla İslâm ve İslâmcılık ile yan yana kullanılıyor olmasıdır. Öyle ki, Twitter profillerinin bir kısmı özgürlüğe dair problemlerin İslâmcılık politikalarından kaynaklandığını imâ ederken; diğer kesim özgürlüğün aslında İslâm'a içkin olduğunu öne sürmektedir. Hatta 
sosyalist ve sol düşünce için de benzer bir durum söz konusudur. Yine de her ne olursa olsun, tüm politik kimlikler için özgürlüğün "kıymetli" bir şey olduğuna dair genel bir mutabakat görülmektedir.

Haklar kavramına geldiğimizde ise, politik kimliklerle kamusal talepler ilişkisinde bir sayısal azlıkla karşılaşıyoruz. "Solculuk, eşit haklar ve adaleti temsil eder."(65) "Burası Türk yurdu; biz Türkçülük yaptık diye başkalarına çeşitli haklar doğmaz, doğamaz."(66) Aynı durum özel hayat, mülkiyet, güvenlik, kanun, anayasa kavramları için de geçerlidir: "Özel hayat beni ilgilendirmez, kamu hayatı ilgilendirir."(67) "İslâmiyette mülkiyet yoktur, emanet vardır."(68) "Komünizmde özel mülkiyet yoktur. Kapitalizmin çarklarını döndüren solcunun olması imkânsızdır."(69) “Özel mülkiyet karşıtlığı, arkaik solculuktur."(70) “...Mülkiyet karşıtlı̆̆1 solculuk bitti." (71) “...Din, milliyet ve mülkiyet tutkunluğu aklın üstüne çıktı." (72) "Milliyetçilik bir ülkede güvenlik, sağlık ve refah sistemi ile inşa edilebiliyormuş. Bunların güçlü olduğu ülkelerde millî aidiyet daha fazlaymış."(73) "Bütün Türkleri tek çatı altında toplayıp, huzur refah ve güvenlik içinde yaşatacak olan tek hareket Türkçülüktür."(74) "İslâmcılık, Türkiye'nin bir numaralı millî güvenlik sorunudur."(75) "Müslümanlık bizim tekelimizde değil. Kanun koyucu yegâne Allah'tır."(76) "Milliyetçilik öyle kuvvetli sosyal bir kanundur ki, ...hiçbir kuvvet onu kaldıramaz, yok edemez."(77) “Türk ve Türkçülük kanun olmalıdır."(78) "İslâmî hükümler göz ardı edilerek kanun çıkarılırsa böyle olur..."(79) “...İnsanlar ve Anayasa, yeteri kadar Kur'an'ın hükümlerini yaşamın bütününe tatbik etmiyor."(80) "İnsanların koyduğu hükümleri 'Anayasa' denen koca defterde toplayıp Allah'ın hükümlerini reddeden laik bir ülkede aynı zamanda Müslüman bir ülkede yaşıyormuşuz."(81) "Anayasa evrensel değerler ışığında yapılmalı, bir kişi ve zümrenin ismi geçmemeli."(82) "Anayasa, bütün alt kimliklerin varlığını temin eden en önemli metindir."(83) Açıkça görülmektedir ki, yukarıdaki kamusal kavramlara ait taleplerin ortak noktası, her talebin bağlı bulunulan politik kimlik ile o kimliğin ardındaki düşünsel sistemden üretildiğinde başarılı olunacağına inanılmasıdır. Yani kullanıcı profillerindeki anlatıya göre, haklar, özel hayat, mülkiyet, güvenlik, kanun, anayasa vb.'leri herkesin kendi politik düşüncesi etrafında kurulduğunda, her şeyin "daha iyi" olacağına dair sarsılmaz bir beklenti mevcuttur. Bu da bizlere politik kimliklerin karşılıklı uzlaşma isteği hakkında bilgi verir. 
Bununla birlikte, inanç ve adalet kavramlarının sunumlarında ise kısmî bir zenginlik seçilebilir: "Her din ve inanç saygı beklemeyi hak eder. Ama inanç bireysel olmalıdır. Din ve hizmet adı altında iktidar, güç ve İslâmcılık için kullanılmamalıdır."(84) “...Türkçüler, 'turan' derken inanç özgürlügünü, Ülkücüler ise Türk-İslâm ülküsünü savunur."(85) “Solculuk, ibadetten, inanç, din, sorumluluk müessesesinden kaçmanın öbür adıdır."(86) "Sağcllık-Solculuk inanç, mezhep ya da etnik kimlikle ilgili değildir."(87) "Ben, inanç fobisi olmayan sosyalistlik, mezhep ve farklı görüş fobisi olmayan bilinçli inançlılık temenni ediyorum"(88) "Müslümanlık, inançtır... Bütün farklılıkları bir arada toplayan devletimiz, inanç ya da ideolojik tanımla adlandırılamaz."(89) "Milliyetçilik, ... iman ve inanç davasıdır."(90) "İslâm, adalet ve ahlâktır."(91) "Devletin dini adalet olmadıkça, siyasal İslâmcılık zulmü bitmez."(92) "Solculuk, eşitlik, adalet, özgürlük, antiemperyalizm, tam bağımsızlıktır.”(93) “...Eşitlik, emek, özgürlük, adalet ve barış gibi değerleri savunmak da bizi solcu ya da sağcı yapmaz."(94) "Solculuk iddiası taşıyan birisinin iyilik, vicdan, şefkat, dürüstlük, bilimsellik, adalet vb. tercihleri olmalı."(95) “Türkçülük bu coğrafyada her şeyin çözümüdür. Devlet yönetimi, adalet, hukuk, eğitim, bilim, yüksek savaş sanatı ne arasanız Türkçülükte var."(96) "Türkçülük, ... adalet, ahlâk ve din sancağını doğudan batıya taşıyan bir mefkuredir."(97) "Türk milliyetçiliği, adalet, hak, hukuk ve verilen sözlerin tutulmasını içerir."(98) Buna göre, sağ siyaset söz konusu olduğunda inanç ve adalet kavramları genelde, soyut (din, iman, ahlâk vb.) durumlarla, sol düşünceye ait sunumlarda ise somut (emek, barış, bağımsızlık vb.) kavramlarla birlikte kullanılmaktadır. Tabi mevcut politik kimliklerin tümü, her türlü problemin çözümü ile tüm kamusal taleplerin yerine getirilmesinin yolunu yine kendilerinde bulmaktadırlar.

Netice itibarıyla, yukarıdaki politik kimliklerde net olarak karşımıza çıkan bazı tutumlar, kamusal talepler söz konusu olduğunda fazlasıyla görünmez hâle gelmekte; böylece istekler politik kimlikler üzerinden değil de sıradan yurttaşlık hakları çerçevesinde talep edilmektedir. Yani özgürlük, bireysel haklar, güvelik vb. kamusal taleplerin neredeyse tamamının, bir politik kimlik eşliğinde sunulmaktan kaçınıldığı görülmüştür. Bunun bir nedeni, kamusal hak taleplerinin bir politik kimlikle beraber sunulmasının talebin meşruiyetini ortadan kaldıracağı korkusuysa eğer, 
diğer bir sebep de talebin kitleselleşmesini sağlamak olabilir. Zira ilk nedene dair korkunun, aynı zamanda bir güvensizlik, nefret ve linç mekânı olarak da kullanılan sosyal medyada karşılığı vardır. İkinci neden de yersiz değildir, çünkü bu sosyal ağlarda kitleselleşemeyen taleplerin hiçbir karşılığı bulunmamaktadır. Bu etkenlerin Twitter profilleri sahiplerini kamusal hak taleplerini dile getirirken etkilediği görülmektedir.

\section{Sonuç}

Bu çalışmayla ilgili veriler göstermektedir ki, Twitter'da sunulan politik kimlikler kendisinden ziyade öncelikle rakip olan/rakip gördüğü kimliği tanımlama/anlatma veya ona dair bir çerçeve çizme önceliğine sahiptir. Buna göre her politik kimliğin (ve dolayısıyla sosyal medya kullanıcısının) sadece "ötekinin tutarlılığı" üzerinden bir politik anlatı sürdürdügü söylenebilir. Bu politik anlatının merkezinde bilhassa ötekilerin ahlâkî, insanî pozisyonları ile (bilhassa yanlışlarıyla) geçmişte ya da bugün yaptıklarının sonuçları yer alır. Yine aynı sebeple, bu politik kimlik sahiplerinin karşılarındakilere yoğun biçimde sordukları soru daima "bu mu?" ile bitmektedir. Solculuk bu mu? Türkçülük bu mu? gibi. Zira herkesin birbirini "sahtelikle" suçlayıp, "samimi" olmaya çağırdığı politik bir dilin bu alana hâkim olduğu da görülmektedir. Bu durum aslında, kişilerin temel derdinin "kendilerini anlatmak" ama kimseyi dinlemek istememek olduğunun da bir göstergesidir. Zaten sosyal medya bir bakıma da böyle bir mekânın adıdır. Kişiler, sanal ya da gerçek kimlikleriyle bir şeyler söyleyip, başka hiç kimseyi dinleyip ciddiye almadan burada vakit geçirebilmektedirler. Hâlbuki "akılcı kamusal müzakere, müzakereye giren kişilerin müzakere öncesi ve sonrasındaki konumları açısından bir değişim olması gerektiğini vurgulamaktadır... Buna karşılık internet birbirine benzer olan kişi, grup ve kanaatlerin bir araya geldiği; kanaatlerin dönüşmekten ziyade mevcut kanaatlerin güçlendiği bir ortama" dönüşmüştür (Özçetin, Arslan ve Binark, 2012, s.72). Dolayısıyla buradaki politik kimlikler, hem karşısındakilere söz söyleyen hem de düşünsel yalnızlıklarını gideren figürlerdir. $\mathrm{Bu}$ yüzden yazılanların beğenilmesi, fazlasıyla paylaşılması, takdir görmesi, ideolojik bir hazza da neden olur. Bu ortamlarda yer almanın, devam etmenin kişisel güven ve motivasyonu da yine buralardan toparlanır. 
Şu da bir başka bulgudur ki, politik kimlikler içerisinde en fazla tepkiyi İslâmcılık ile İslâmcı/Müslüman kimliği çekmektedir. Tanımlama, savunma ve nefret etme eylemlerinin odağındaki bu kimlik, diğerleri için neredeyse ortak bir yaygın kanaatler merkezi gibidir. Hatta özgürlük, kanun, güvenlik, adalet gibi pek çok kamusal talebe ulaşma konusunda engel/tehlike olarak da görülen İslâmcılık, bir taraftan devlet aracılığıyla uygulanan bir baskı vasıtası şeklinde tanımlanırken, öteki taraftan da güncel sorunların sebebi olarak nitelenmektedir. Mevcut politik iktidarın uygulamalarının bir sonucu olarak görülebilecek bu tepkilerin artık İslâmcılık'tan çıkıp, doğrudan İslâm dinine yöneldiği de yine aynı tespitler içerisine alınmalıdır. Dahası yine bu konuda bilhassa İslâmcılık ile "Türklük" arasındaki farklılığı anlatmaya yönelik twit'lerin yoğunluğu da dikkat çekmektedir. Özellikle Türkçü ve milliyetçi profillerde İslâmcilığın, Türklüğün "en büyük tehlikesi" olduğuyla ilgili söylemlerin çokluğu buraya eklenebilir.

Diğer taraftan, yukarıdaki verilerden de anlaşlacağı üzere, Twitter'daki politik kimlikler kendilerinin "nasıl olduğunu" anlatmaktan çok "nasıl olmadığının" ispatlarıyla doludur. Bu da bizlere sosyal medya ortamlarının çekişmeli hallerinin, demokratik bir kamusallık ile uzlaşmacı rasyonel ilişkileri nasıl zedelediğini işaret eder. Üstelik kişilerin bu sosyal mekânları bir "kapışma/hesap sorma ortamına" dönüştürme çabalarının da buna neden olduğu söylenebilir. Sıklıkla kin, tahammülsüzlük ile öfkelerin hâkim olduğu ve buna yönelik paylaşımların yapıldığı bu kamusal karşılaşma ortamları, bu yönüyle bir kamusal müzakerenin ortaya çıkma ihtimalini de zayıflatmaktadır. Kullanıcıların sürekli olarak rakip politik kimliklerdekilerin tümünün aslında "birbirinden hiç farkı olmadığına" yönelik husumet içeren paylaşımları da bu yönelimi destekler. Yine de bazı küçük grupların ortak toplumsal sorunlar üzerinden (bilhassa kadınlar, çocuklar ve hayvanlara yönelik şiddet ve suçlarda) kamusal bir ilişki ile "tanımaya" yönelik bir müzakere ortamı oluşturdukları da seçilebilir. Bu sebeple sosyal medya, Habermas ve Rawlsçı anlamda bazı kamusal işlevlere sahip olurken, Sennett ve Arendtçi anlamda kamusal çöküşün mekânıdır.

Bununla birlikte, ele alınan politik kimliklere ait söylemlerin, slogan, klişe ve ezberlerle dolu, derinliksiz metinlerden oluştuğu da belirtilmelidir. Bu nedenle, bütünlüklü ve tutarlı olma sorumluluğundan uzak 
bu metinlerin bir ortak ahlâk normuna dayanma konusunda zayıf oldukları da gözlenmiştir. Kamusal talepler söz konusu olduğunda ise politik kimliklerin her birinin, sadece rakip kimliklere karşı değil, kendi içerisinde bile pek çok alt yoruma bölündüğü de buraya eklenebilir. Bu bölünmenin sebebi olarak, etkili bir düşünsel zemin ihtiyacı, güvensizlik ile adalet ve dayanışma yokluğunun yarattı̆̆ı öfke ve zihnî parçalanmışlığın etkileri sıralanabilir. Keza bu parçalanmışlığın kökenleri politik kimlikler de dâhil olmak üzere, Bauman'ın "sınıf-altı kimlik" dediği, kimlik şekillerinde aranabilir. Çünkü sınıf-altı kimlik, aslında "kimliğin yokluğudur. Etik görevin ve ahlâki kaygının hedefi ve amac1 olan bireyselliğin ve 'yüzün' reddi; hatta silinmesidir" (Bauman, 2017, s.52-53). Dolayısıyla, kimlikler silikleştikçe bir öz arayışı da ("gerçek İslâm/Türkçülük/solculuk bu değil!" gibi) ortaya çıkmaktadır. Dahası, politik kimlikler için olduğu kadar, kamusal talepler için de standartlaştırıcı bazı istekler belirmekte, bu da olası talepleri belirli ve sığ bir dile hapsetmektedir.

Sonuç itibarıyla, politik kimlikler söz konusu olduğunda, kamusal taleplere dair kullanılan söylemler dar ve tahammülsüz olmaktadır. Meselelerin kitlesel değil de kişisel olarak ele alınması gibi etkenler, Twitter ortamını klasik kamusal alanın ötesinde kamusal sorunların paylaşıldığı bir yer haline getirse de bu sorunların tartışılması soyutlama düzeyine bile erişememektedir. Dahası kamusal problem ne olursa olsun politik kimliği aklamaya yönelik çabaların çokluğu, ortak ve birlikte yaşamaya dair beklentileri de zayıflatmaktadır. Dolayısıyla tüm bu bulguların, insanların kamusal talep ve beklentilerini anlama adına önümüzdeki yıllarda sosyal medya ortamlarının daha çok tartışılması gereken yerler olacağı da kısa vadede öngörülebilir bir gerçekliktir. 
EXTENDED ABSTRACT

\title{
Social Media as The New Venue of "Political Acti- vity" of The Changed Publicity - (The Case of Twit- ter in The Context of The Relations Between Politica- IIdentities and Public Rights)
}

$*$

\author{
Yavuz Çobanoğlu \\ Munzur University
}

When it comes to man, society and state and the relations among them, interest of sociologic researches focuses on what is political however, detection of it actually indicates an ontological circumstance. The ontology of what is political is about what can be dealt with as 'political' under certain circumstances and how it can be made more comprehensible in terms of politics. Besides it can be said that political sociology emerged as a result of such necessities and these very necessities derived from difficulties in comprehending politics and the concepts emerge with it with sociological paradigm. Thus, political sociology emerged and grew as a scientific field which aims at gathering information about political system: reactions and behaviours created by political ideas: ideologies: symbols, the impact of language and discourse on masses: mechanisms of democracy and parliamentary institutions: differentiations between society and state etc. and reasons and impact of all these issues.

\section{Public Sphere and Altering Perception of Publicity}

The terms public, public sphere and publicity derives back to ancients ages; however, the time period during which the discussions concerning these very terms raised intensively refers to modern era because the discussion on various terms such as nation state, civil society, civil rights, democracy, individual and freedom became the main interest of social sciences with an intensity as it had never seen in the history. Consequently public sphere became a phrase which depicts a mutual ground for social 
interaction in which all citizens make easy contact with each other by all means using vast public means without barriers or limitations. According to this concept, citizens have the right to affect or supervise the state by legal means provided within public sphere. What Habermas meant by the term public sphere is that all citizen have the right to enter and gather in this very sphere to think freely of any issues; it is a collective area where mutual ideas are found and formed. This is not only an area for thinking and gathering freely but also a setting where various believes and identities are presented to the others. Public sphere concepts is not limited to the theory of 'public sphere of bourgeois' by Habermas. 'Republican public sphere' by Hannah Arendt, 'liberal public sphere' by John Rawls and corruption of public man' also contribute a great deal to the issue.

\section{Identity as a Social Setting}

Identities are the most conspicuous social aspects that people present in the outside world. Identity which depicts itself in human actions in a specific way of sociability are also a part of individual struggle for being known and recognized in a cultural setting. Furthermore, it does not matter what kind it is, an identity is something cultural. It is born and formed in a cultural setting; it also changes or is presented in this very setting since the cultural realities of human communities are a reflection of their collective structures. Thus, this kind of factors can be seen as a proof that identities go through a certain formation process. Identity is a name given for a regularity/continuity, which is formed collectively and embodies collective partnerships, based on reciprocity principle. It is because of this very characteristic that 'collective identity depicts a process not a specific circumstance.

\section{Presentation of Political Identities on Social Media as a New Setting for Publicity}

All internet environments, especially social media, are seen as democratic settings where ideas are formed and shared or where they collide or are discussed when interacted. It is also accepted as a setting where people have the opportunity to express their personal or social problems. This is 
also an environment where all kinds of political, ideological or perceptional operations or deformations can be made. It is also possible for some countries or even people to control this environment easily under the care of leader states of technological production. Moreover, social media may be used as a tool to build up hate and violence instead of democratic principles, compromise or recognition. In fact internet and social media networks have many characteristics which can justify these two different attitudes.

\section{Method}

Mentality, language or discourse, is a text. Revealing the concept sets in this text also stands for elucidating its social, economic, religious, moral or ideological semantic world and the research method to make social media presentations more explicit must be content analysis because it can be accepted as a new study in terms of detecting political or mental processes people go through involuntarily or content and comments hidden within the texts that emerges during communication. Moreover, all communicative processes enabled by communicative means are of this method's field of application.

\section{Conclusion}

The data concerning this study show that political identities presented on Twitter aims at describing or framing another rival identity rather than itself. Owing to this fact, it can be said that each political identity holds a political narrative based on 'consistency of the other one'. When it comes to political identities, statements concerning public demands become narrower and more intolerant. There are various factors such as considering the issues individually rather than collectively. Although these factors turn Twitter into a setting where public issues are shared beyond classical public sphere, discussing these issues cannot even reach an abstraction level. Moreover no matter what the public problem is, the efforts to justify a political identity are in such an abundance that the expectation of living harmoniously is weakening. Thus it is a reality that in the following years 


\section{all these findings will most likely lead to discussions in terms of under- standing the puclic demands and expectations of people.}

\section{Sıralı Ekran Çıktıları:}

1

1. "İslâmlașmak demek, İslâm'ın itikâdiyâtını, ahlâkiyâtını, içtimâiyâtını siyâsiyatını daima zamanın ve muhitin ihtiyâciyâtına en muvafık bir surette tefsîr ederek bunlara gereği gibi tevfîk-i hareket etmekten ibarettir." [Said Halim Paşa]

2

"Hislamcilik, Bati'ya meydan okumadir" goo.gl

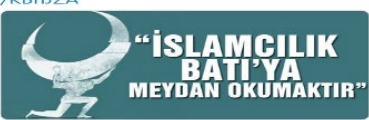

"İslamizm/İslamcllık İslam değildir, ama onun bir ürünüdür. Bir İslam teokrasisidir." \#ISID \#Daesh \#islamcllık

wsj.com/articles/how-t .

$$
\begin{aligned}
& \text { 12:05 }-12 \text { Are } 2015 \\
& \text { \#islamcilik }
\end{aligned}
$$

"islam;müsıümanın kötülüğe karșı durma sorumluluğunu yerine getirmes ve insanların Allah ile bağlarını koparmaya çalışan güçlere karşı mucadelesidir" Alev Erkilet |

Ahlaken müslümanlaşamayanların siyaseten islamel lik yapmalarl en çok islama zarar veril... Ayrıca islamcilık diye bi şey yoktur. Bir Allah bir kur'an ve bir islam vardır. Biz oynamayız gereken neyse onu

yaparız,yapıyoruz,yapacağız. Inancimiz ve inandıgımız gibi! Uydurulma terimlerle ve icerikleriyle isimiz olmaz. Buyurun yilbası.
kutlayın. Kimsenin size afkurdugu yok!

islamclık, modernist bir kafayla, pozitivistsimdilerde postmodernist- bir zihniyetle İslamı yorumlamaktır. İnanmaktan öte yorumlamak. twitter.com/oguzhanbilgin/ ...

İmanın korunmadığı ve yaşanmadı̆̆ı yerde küfür sultandır. Müslüman için iman hayattır, candır. İman, Müslümanın damarında kesintisiz dolaşan kandır. İman olmayınca Müslümanlık iddiası tümden yalandır!

@mustafaislamogl aslında doğru kelime șu olmalı, "müslüman gibi görünüp, kendini bilinçsizce müslüman zannedenlere inancım yitirdim " çünkü bilinçsiz müslümanlık = düşüncesiz, cahil ve pasif iyi aktif kötü insana eșittir.
Cencim sağcı veya solcu olmak suç degi ideolojidir yaşam biçimidir şayet aşırıya ırkeı olur senin anlamadığn konu bu dostum 3

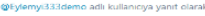

Türkçülük üzerine kurulan solculuk kimseye fayda sağlamaz. Temel bileşen HDP yi yok sayan bir zihniyet solcu olamaz. Kürt kelimesini dahi söylemeye çekinen biri yaptığ kelimesini dahi soylemeye çekinen biri yaptığ 2 sekonomik hamleyle solcu olamaz. Olsa olsa yerel

Aslında Türkiye'de dünyada olduğu manada bir solculuk neredeyse yok! Bütün dünyada işçiler, ezilenler solcu iken Türkiye'de burjuvalar solcu olmuş, oluyor...

Koministlik de Solculuk da Solculuk da Emperyalistlerin kullanışı

PIYONLARIYDI..Türkiye de ki Kamu Kurum ve Belediyelerine çökmüș KÜP doldurup zengin olan ve lüx içinde yaşayan Atatürkçü Solcu darbeci CHP lilerin TAMAMI KAPITALISTTIR

Devrimcilik sola yakındır desek yalnıs olur,solculuk devrimcilige yakındır,o yuzden içinde insanlığı yasatan ve onun için mücadele eden herkesin kendini solcu gibi hisetmesi ondandır...

Devrimcilik solculuk degildir buna hep karşıyım, Her solcu devrimcidir diyebilirz ama her devrimci solcu değildir,devrim bir yapbozun bütünü gibidir,solculuksa o yapbozun birer parçasıdır.

Sosyalistlik sözel, zihinsel bir eylenme alan değil, yaşamın tüm alanlarını kapsayan sınıfsal ve kișisel bir duruștur, seçilmiș ve yașama geçirilmis bir kimliktir. Bu açıdan bakınca bilinen sosyalistlerin hiçbiri gerçek sosyalist değildir. Çoğu iyiniyetli lümpendir.

Demokratlık ve sosyalistlik, birbirini tamamlayan ilkelerdir;demokrat olunmadan sosyalist ve sosyalist olmadan da, demokrat olunmaz.

16-42 - 8 May 2018

Sosyalistlik diy birşey yoktur anarşi peşinde kosan din imanla alakası olmayan siddetle beslenen kişidir sosyalist eşitlik kardeşlik hikaye

19:28 - $22 \operatorname{Tem} 2015$

Türkiyemde sosyalist koministlik dinsizlik veya imansizlik demek degildir ;sosyalistlik koministlik hakca bölüşüm hakca adalet demektir; 
Değişen Kamusallığın Yeni “Siyaset Yapma” Mekânı Olarak Sosyal Medya - (Politik Kimlikler ile Kamusal Haklar İlişkisi Bağlamında Twitter Örneği)

11

Bunlar birde müslümanın diyor şerefsiz

bunlar...müslümanlik, hosgörüdür

müslümanlık affetmedir, Müslümanlık kulu sevmedir...bunlar mı Müslüman.

12 Müslüman Müslümanın kardeşidir.Ona zulmetmez, düş̧manınateslim etmez Hadisi yasasınor.Bana dokunmayanyllan bin yaşasın modundan çıkılamadığından a aülämiyor.Devletlerde bencillik hüküm suruyor.Muslumanilik isimde kalıyor.Zulüm ölüyor

Başta kendimizi bir sorgulayalım. İslam veya Müslümanlık çocuk oyuncağı değildir. Mıs gibi yapmak hiç değildir. İsimize gelince müslüman gelmeyince gavur olma ihtimalimiz var mı yok. Veya bir ortamda seküler digerinde şeriatçı. Geçin efendim...

Müslümanlık parayla namla șanla olmaz Müslüman ALLAHIN Şeriatına yani emirlerine uymakla yaşamakla olur

Müslüman Doğruya doğru yanlıșa da yanlış diyebilmelidir Müslümanhlık budur

Hepimiz Milliyetçiyiz. Lakin asla Milliyetçiliğimiz \#Müslüman oluşumuzun önüne geçmesin! Aksi halde helak olmamak kaçınılmazdır! Mühim Olan Müslümanlık çatısı altında toplanabilmektir! Hepimiz Hz.ADEM ile Hz.Havvadan gelmekteyiz ! Bu sonradan olma \#milliyetçilik hırsı neyedir!

17 Müslümanlık dilde olmaz ezbercilikte olmaz. Önce İnsan olmayı öğreneceksin insan olduktan sonra atalar dinini tek ederek kend aklınla vicdanınla sorgulayarak araştırarak Rabbini bulur ve secde (teslimiyet) eder Müslüman olur.

Doğruluk Müslümanın şiârıdır, Müslümanlık göstergesidir. Yalancılık ise münâfığın șiârıdır. nifak göstergesidir. Bu yüzden Müslüman asla yalan söylemez, yalana pirim vermez, yalan yere yemin etmez ve yalancı sahitlik yapmaz. Aynı sekilde o. yalanın katmerlisi iftirâdan uzak durur

İslamcılık iflas etti demek bu İslam anlayışıyla ve bu Müslümanlarla iflas etti demektir. Yoksa yeni bir İslam tasavvuruyla ve yeni bir Müslümanlık anlayıșyyla yeniden deneme Müslümanlık anlayışıyla yeniden den
yapmak her zaman mümkündür ve yapmak her zaman mümkündür ve
yapılmalıdır.Ancak bu defa Müslüman yapılmalıdır.Ancak bu defa Müslüman
olmayanları da kușatacak șilde olmalı

e karşı olan, zenginliğin eşit dağılmasını isteyen, siyasal, ekonomik alanda kökten değişiklik amaçlayan bir akımdır.

Ak çomarlar öyle bir algı oluşturuyorlar ki teröristler solcu olur tarzında yazıktır. Vatan uğruna çok Denizler, Yusuflar öldü bu ülkede.

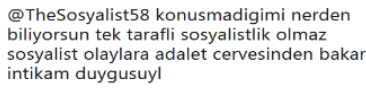
biliyorsun tek tarafli sosyalistlik olmaz sosyalist olaylara adalet cervesinden bakar intikam duygusuyl

2028 - 5 Agu 201

Türkçülük bir ülkü, siyaset ise iktidara geçme taktiğidir. Bu sebeple bir ana inanç ve ana düşünce olan ülkü asla değişmediği halde siyaset yani taktik her zaman değişir.

Türkçülük kötü bir şey değil. Irkçlık kötü bir şey. Aradaki ince çizgilerimi anlayacak kafada olmadığı için, Türkçü kişilerle iletişimime anlam veremeyen dangozlar var maalesef.. Bir gün ülkede milliyetci gecinen politikacılar, yöneticiler, sanatçılar, aydınlar hiç bir cıkar kaygısına düşmeden, yiğitçe, korkusuzca Türkçü söylemlerde, Türkçü tavırlarla milletin karşııına çıkarlarsa o gün Türkçülük büyük bir utkuya yaklaşır. \#AtsızDiyorki

\#AtsızDiyorki Türkçülük ülküsü bizden amansız bir görev ahlakı istiyor... Her Türkçü bulunduğu yerin görevini inançla yaparsa, Türkçülük ülküsü sağlamlașır. Türklük güçlenir.

Ülkücülük genel yapısı itibarı ile ırkçı değildir, C. Türkçülük genel yapısı itibarı ile kandaştır !

Ülkücülük aksiyona ve reaksyona dayanır, C.Türkçülük fikre dayanır

C. Türkçü Türkten başka dostu olmadığın bilir, ülkücü için müslüman olmak kaydı ile herkes kardeştir

Atsız

Sevmek Türkçü bir eylemdir. Türkçülük, ayrımcılık değil seçiciliktir. Kalite, seviye, kıymet aramaktır. İkisi de taş olsa da kömür ile elması bir tutmamaktır. Her insanı bir tutmamak, sevilmeye lâyık olanı kayırmaktır. Her milleti bir tutmak, çiçeğe ot muamelesi yapmaktır.

Bizim Türkçü olmamız, bozkurt işaret yapmamı herhangi bir siyasi partiye mensup olduğumuz anlamına gelmez. Türkçülük siyaset üstü bir fikirdir.

Türkçülük kimsenin dini inancını sorgulamaz, her inanca aynı mesafede durur.Bunu yapıyorsan sen zaten Türkçü olamazsın. Bazı arkadaşlar Türkçülüğü başka ideolojilerle karıştırıyor.

08.37 - 28 Ara 2018

"Biz Türk'üz, Türkçüyüz ve daima Türkçü kalacağız. Bizim için Türkçülük Bir kan meselesi oldugu kadar bir vicdan ve kültür meselesidir.Türkçüyüz ve her vakit bu istikamette çalışacağız." 

anlamı millet ve vatan sevgisidir.

Herhangi bir ölçütü yoktur. Tahsil birikim ve kültürel altyapı aranmaz.

Bir milliyetçi Türkçü olmak zorund değildir ancak bir Türkçü milliyetçi olmak

\#Türkçülük kimsenin dinini,inancını sorgulamaz,sormaz, yargılamazÖnemli ola soy birliğidir, kan kardeşliğidir. \#Türk Töresin özümsemek, \#Türk'lük bilincine

ulasmaktır.Insanların inancları ile uğraşmak, hor görmek ya da tavır almak . \#Türkçü

Türk milliyetçiliğinin temelini ülke sevgisi oluşturur ( bu ülke tam bağımsızdır ve dili Türkçedir), siyasi partiyle milliyetçilik olmaz ve bu ülkede her siyasi hareket milliyetçi olmak zorundadır değilse bu ülkeye ait değildir.Bu ülkeye ait olmayan gereksizdir.

44 Amerikan güdümlü milliyetçilik, ancak uşaklığı kuvvetlendirir. Milliyetçilik her şeyden önce bağımsızlıktır, bağımsız karar alabilme yeteneğine sahip olmaktır. Milliyetçi, akıllı olmak zorundadır.

Vatan, Bayrak, Milliyetçilik olmadan Olmaz! Atatürk milliyetçi olduğu için kazanmıştır.

46 Milliyetçilik, hem sosyal, hem kültürel, hem ekonomik, hem politik ve hem de askeri cephesi ile bir bütündür. Milliyetçi; her sahada milliyetçidir.

Irkçוlık ve milliyetçilik birbirinden çok ince bir çizgiyle ayrılır. O çizgi de başka milletlere zarar vermeye baslayinca ırkçı olursun. Baska milletlere saygın oldugun da milliyetçi

milliyetcilik millet ve vatan sevgisi ise anti emperyalist olur

ümmetci den milliyetci olmaz olamaz ..

Atatürkçü olmayan Türk milliyetçisi olama Onlar kendisini milliyetçi diye adlandıran siyasi islama hizmet eden sentezcilerdir.
Bugün milliyetçilik görüşunun temellerinin tek oturduğu kesim Türkcülerdir. Her kesimin milliyetçiliği farklıdır derseniz aynı yolda olamayı.

Milliyetçilik şekilcilik degildir Milliyetçiyim liyetcisi Milletin sorunlarr yasam kalitesinin yükseltilmesi üretime katkı dişa bagımlı olmama gibi edebiyatı yapan șekilciler görünüște Milliyetçi aslen gericidir

Milliyetçilik belirli bir zeka seviyesi ister. Özellikle Türk olup milliyetçi olmayan insan aptaldır.

Bu kadar ihaneti bu kadar düșmanlığı göremeyen Türk helak olsun

52 Genç nesillerini milliyetçi olarak yetiștiren milletler, geleceğe güvenle bakabilirler. Milliyetçilik; mensubu olduğu milleti ilerletmek, yükseltmek, milli değerleri korumak ve geliştirmek duygusu ve şuurudur. işte bu işin bi ortasını bulmak gerek. Savaşmak değil de belli bir yaşam alanında özgürlük tanımak gerek. Sosyalistlik budur

$$
\text { 22:30 - } 8 \text { Ağu } 2016
$$

sosyalistlik dinsizlik değildir, bunu sokun kafanıza.

sosyalizm hoşgörüdür. inanca saygı

düşünceye

özgürlük.

05:11 - 3 Ağ 2013

Alman kurdu ile Türkçülük yapan, Husky ile Türkçülük yapan çoktur. Fakat sorun şu ki, gerçekten bozkurt ile Türkçülük yapan yoktur. Çünkü bozkurdun yanına yaklaşamazsınız. Şimdi anlaşıldı sanırım neden Türk'ün simgesi bașkası değil de Bozkurt'tur. Çünkü özgürlük kutludur.

"ilkel milliyetçilik"söylemi yerlilerin kültürüne ve diline karşı sömürgeciliğin bașvurduğu bir saldırı stratejisidir

Oysaki milliyetçilik ezilen uluslar için bir özgürlük ideolojisidir"

Solculuğun karşıtı neden dindarlık?.. Solculuk eșit haklar ve adaleti temsil eder, dindarlık neden bunun karşıııı temsil ediyor?

+eğer bundan rahatsızlık duyanlar varsa işte kapı oradadır. İsteyen istediği ülkeye gidebilir. Burası Türk yurdu arkadaşım, biz Türkçülük yaptık diye bașkalarına çeșitli haklar doğmaz, doğamaz.

\#YaşadıkçaTürkçüyüz

@akaya1299 Müslümanlık değil ve cogunun yaptıgı bu. Özel hayat beni ilgilendirmez kamu hayatı ilgilendirir en cok orda insalar $>>>$

04:21- 6 Ey 2013

"Islamiyette mülkiyet yoktur emanet vardır. Yetimler de emanettir. Yetimlik varsa müslümanlık eksik yaşanıyor demektir. "\#SahurVakti

03:35 - 12 Haz 2017

Solculuk komünizme taraftarlığı, sağcılık kapitalizm taraftarlığıdır. Komünizmde özel mülkiyet yoktur. Kapitalizmin çarklarını döndürenlerin solcu olması imkansızdır. İdeolojileri ekonomik ve hukuki yapıları açıklamasıyla tanımlamalıyız.

@hakanvshakan özel mülkiyet karşıtlığı bir solculuk arkaik zaten.

11:30 - 3 Tem 2015

DOĞA KOLEJiNE uğrayın da çocukların anne babalarını sorun bir de siyasi görüșlerini.. yemeyin bizi.. mülkiyet karşıtı solculuk bitti 11:52 - 1 Ara 2013 Torkiye konumundan

72 Ülkemizde ve benzer ülkelerde din,milliyetçilik ve mülkiyet tutkunluğu aklın üstüne çıkmışıı... 
Değişen Kamusallığın Yeni “Siyaset Yapma” Mekânı Olarak Sosyal Medya - (Politik Kimlikler ile Kamusal Haklar İlişkisi Bağlamında Twitter Örneği)

53 Adalet, özgürlük, nezaket, merhamet önerisi olmayan bir islamcılık içine çöker, çöküyor.

06:27-21 May 2017 Georga kooumun

54 Tarihte İslamclikk ile onur, bağımsız||k, özgürlük gibi kavramlar yan yana anılmaz. Bu bir görselli islamellk tarihi floodudur. laiklik istemek özgürlükse niye şeriat islamcılık istemek özgürlük dehildir bumu demokrasiniz

56 İnsanlığın basındaki bela basta ırkçılıktır seryatciliktir ve gilodiyonun bu üç olgu insaligin düşmanıdır bu yüzden Müslümanlık reform edilmeli kadına özgürlük sağlanmalı insaligin geleceği icin

DIN bir seçimdir İSLAMIYET zaten özgürlük dinidir dayatma değil TÜRKLÜK ise kader şahsen ben seçimimi Müslümanlık olarak kullanmışım çoğu TÜRKÇÜ kardeşimde benim gibi düşünüp İslamiyeti seçmiştir.

İslamcıların özgürlük anlayışlarının sadece islamcılık özgürlüğünden ibaret olması sorunsalı. Mağdur edebiyatı da cabası amk $20: 11$ - 2 Nis 2018

Sağcıllk veya solculuk mevzusu değildir. Sorun özgürlük ve temel hak sorunudur. Bir halkın dil ve kimlik sorunudur. Bu sorun çözülmediği sürece Türk emekçisi burjuvazinin savaş arabasına koşturulacaktır.

Sağcılık Biat, gelenekçi (yanlışlar dahil) eskiye bağlı, yeniliğe, farklıı̆ga karşı komün anlayış demektir.

Solculuk "Eșitlik, Adalet, Özgürlük, Hosgörü" kavramlarını, İslamiyetin temel kavramlarını savunur. Müslümanlar Sol düşünceye inanmalıdır. İslam Sol tandanslı bir dindir

81 \#ögrencievlerinemühür İnsanların koyduğu hükümleri anayasa denen koca defterde toplayıp Allah'ın hükümlerini reddeden LAík bir ülkede ama dediklerine göre aynı zamanda MÜSLÜMAN bir ülkede yaşıyormuşuz. Laiklik ve Müslümanlık ateşle barut gibidir. İkisi aynı yerde BULUNMAZ!

solculuk evrenseldir.Kemalizm bir ülle liderinin idolojisidir.o nedenle kemalizm solculuk değildir.Anayasa evrensel değerler ışığında yapılmalı bir kişi ve zümre nin ismi geçmemeli. kemalist solcu olabilir.ama solculuk kemalizm değildir.

Milliyetçilik bir ülkede güvenlik, sağlık ve refah sistemi ile inşaa edilebiliyormuş. Bunların güçlü olduğu ülkelerde milli aidiyet daha fazlaymış Bütün Türkleri tek çatı altında toplayıp, huzur refah ve güvenlik içinde yaşatacak olan tek hareket \#Türkçülük'tür.

18:13-10 Ek 2014

islamcılık Türkiye'nin bir numaralı milli güvenlik sorunudur. Bu sorun çözülmeden Türkiye'ni yol alması mümkün değil.

Müslümanlık bizim tel elimizde değil. Kanun koyucu yegane Allah'tir. O Allah ki hal olan ilahtir. Bizi onun kanunları kapsar karar verebilmek icin 18 yaşımı beklemek Tc kanunudur.

Milliyetçilik, öyle kuvvetli sosyal bir kanun, öyle müthiş bir hakikattir ki, hiçbir kuvvet onu kaldıramaz, yok edemez.

TÜRK VE TÜRKCÜLÜK KANUN OLMALDIR. ÇÜNKÜ TÜRKÜYENINN KURUCUSU TÜRKDÜR. ULLU TÜRK ATATURKTUR. ALLAH RAHMET ETSIN.

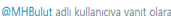

İslami hükümler gözardı edilerek kanun çıkarılırsa böyle olur,islam yerine islamcılık oynayanlara dikkat.

Turkiyede yeteri kadar laiklik de var yeteri kadar milliyetcilik de var

Ama yeteri kadar müslümanlık ve islam yok yani insanlar ve anayasa yeteri kadar kuranın hükümlerini yaşamın bütününe tatbik etmiyor.

Bu nedenle refah partisi misyonunu artık hudapar rehberligi üstlenecek

Milliyetçilik gelenek,ahlak,fazilet, asalet,iman ve inanç davasıdır.

Milliyetçilik devlet, millet, adap ve ebed müddet davasıdır

Bütün bunlarla birlikte çağlar üzerinden atlayıp çağdaşlaşma davasıdır. NE MUTLU TÜRKÜM DİYENE...

Hep Romantik islamcilik kokan hareketler bunlar, islam'in icini bosaltip böyle sacma sapan seylerle dolduruyorsunuz, halbuki islam Adalet ve Ahlaktir, ama bunu söylemek kimsenin isine gelmiyor.

Balyoz mağduru Özden Örnek 1223 gün tutuklu kalmıstı. etti. Bir baba haksız yere 1223 gün uzak kaldığı oğluyla geçiremediği zamanları düşünerek Devletin dini adalet olmadıkça, siyasa

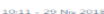



bireysel olmalıdır. Din hizmet adı altında. iktidar, güç ve islamcilık için kullanılmamalıdır. Türkiye cumhuriyeti laik ulus devlettir. Çatısı budur.

Ülkücülerin aslında temelinde Türkçülük Ulkucalerin aslinda temelinde Turkçü yatar.Onlarn úmmetçige yonlendiren siyasetlerinin içine dahil edilen islamcilık olgusudur.

Turan derken inanc özgürlügünü ülkücüler ise Türk-İslam ülküsünü savunur.

Solculuk ibadetten, inanç din sorumluluk müessesinden kaçmanın öbür adıdır o cografyada. Dünyada ise din müessesinden bağımsız, viccdanlı yașamanın öbür adıdır. Kavramların bile yanlıs konuşlandığı bir coğrafya orası. Hiçbirşey garip gelmiyor artık.

Sağcılık - solculuk inanç, mezhep ya da etnik kimliklerle ilgili değildir. Kapitalist düzende ezenler ve ezilenlerle ilgilidir.

@tolgakzn ben inanç fobisi olmayan sosyalistlik mezhep farklı görüş fobisi olmayan bilinçli inançlılık temmeni ediyorum vicdan saygı sevgi
Solculuk; eşitlik adalet, özgürlük, antiemperyalizm, tam bağımsızlıktır. Akıldır, vicdandır, emektir. Etnik ayrılıkçılık değildir!

Solculuk kimseyi dinden çıkartmaz. Eșitlik, mek, özgürlük, adalet ve barıs gibi değerleri savunmak da bizi solcu ya da sağcı yapmaz.

Allah'a ve Resulüne inanan herkes

Müslümandır. Siyasi düșünceleri nedeniyle insanları ötekilestirmek İslam'ın sözüne de ruhuna da aykırıdır.

Profil yazınızı beğenmedim. İnsan doğası gereği iyilik ve kötülük içerir. Solculuk iddias taşıyan birisinin iyilik, vicdan, şefkat, dürüstlük, bilimsellik, adalet vb tercihleri olmalı. @ccanannnn

Türkçülük bu coğrafyada her şeyin çözümüdür. Devlet yönetimi, adalet, hukuk, eğitim, bilim, yüksek savaş sanatı.. ne ararsanız Türkçülükte var. Kanıt? Bkz. 1923 1938 arası.

Türkçülük ırkçılık degildir üstadım. Türkçülü bir mirası, mefkureyi sırtlamaktır. İslam'a Türayir degildir ziralslama da oniras in sancağını doğudan batıya tasııan bir mefkure bölücü olabilir mi?

Türk milliyetçiliği, adalet, hak, hukuk ve verilen sözlerin tutulmasını içerir beyefendi. Sizin milliyetçilik tanımınız \#EmeklilikteYaşaTakılanlar tarafından rafa kaldırıldı.

\section{Kaynakça / References}

Arendt, H. (1994).İnsanlık durumu / Seçme eserler, (Çev: Bahadır Sina Şener), İstanbul: İletişim Yayınları, 1. Baskı

Bilgin, N. (1994).Sosyal bilimlerin kavşă̆ındakimlik sorunu. İzmir: Ege Yayıncılık, 1. Baskı

Bilgin, N. (2000). İ̧̧erik analizi, İzmir: Ege Üniversitesi Edebiyat Fakültesi Yayınları, 1. Bask1

Bauman, Z. (2017).Kimlik, (Çev: Mesut Hazır). Ankara: Heretik Yayınları, 1. Bask1

Dijk, V. (1991). The interdisciplinary study of news as discours. A Handbook of Qualitative Methodologies for Mass Communication Research, (Edited By: Klaus Bruhn Jensen ve Nicholas W. Jankowski), London: Routledge, First Edition 
Durmuş, M. (2012).Yeniden kamusallık! Kamusallığı yeniden tanımlamak ya da yerine devrimci bir seçenek koymak.Türk Tabipler Birliği / Mesleki Sağllk ve Güvenlik Dergisi, Temmuz - Aralık, 34-48. http://www.ttb.org.tr/dergi/index.php/msg/article/view/35/23 (Erişim Tarihi: 25.11.2018)

Fraser, N. (2004).Kamusal alanı yeniden düşünmek.Kamusal Alan, (Der. ve Çev: Meral Özbek), İstanbul: Hil Yayınları, 1. Bask1

Habermas, J. (1995). Kamusal alan: Ansiklopedik bir makale.Birikim Dergisi, 70, 62-66

Habermas, J. (1997). Kamusallığın yapısal dönüşümü, (Çev: Tanıl Bora ve Mithat Sancar), İstanbul: İletişim Yayınları, 1. Baskı

Holub, R. C. (1991). Jürgen Habermas / Critic in The Public Sphere, London and New York: Routledge, First Published

Kerestecioğlu, İ. (2011). Feminizm tartışmaları 8, Amargi İstanbul Feminizm Tartışmaları, İstanbul: Amargi Yayınevi, s. 157-174

Laclau, E. (1995).Siyasal kimliklerin oluşumu. (Çev: Ahmet Fethi), İstanbul: Sarmal Yayınevi, 1. Baskı

McGuigan, J. (1996).Culture and the public sphere. New York: Routledge, First Published

Minarlı, M. A. (2014). Habermasçı burjuva kamusallığının demokratik içeriği.FLSF (Felsefe ve Sosyal Bilimler Dergisi),18, 153-172

Morley, D. ve Robins, K. (1997). Kimlik mekânlari, (Çev: Emrehan Zeybekoğlu). İstanbul: Ayrıntı Yayınları, 1. Baskı

Rasmussen, T. (2008). The Internet and Differentiation in The Political Public Sphere. http://www.nordicom.gu.se/common/publ_pdf/269_rasmussen.pdf , s.73-84 (Erişim tarihi: 27 Aralık 2018).

Özçetin, B. ve Arslan, U. T. ve Binark, M. (2012). Türkiye'de internet, kamusallık ve demokratik kanaat oluşumu, Folklor / Edebiyat Dergisi, 18(72), 51-76.

Rawls, J. (2007). Siyasî liberalizm, (Çev: M. Fevzi Bilgin). İstanbul: İstanbul Bilgi Üniversitesi Yayınları, 1. Baskı

Sarıbay, A. Y. (1998). Siyaset, demokrasi ve kimlik. Bursa: Asa Kitabevi, 1. Bask1

Sarıbay, A. Y. ve Öğün, S. (1998). Bir politikbilim perspektifi. Bursa: Asa Kitabevi, 1. Bask1 
Sarıbay, A. Y. (2000). Global bir bakışla politik sosyoloji. İstanbul: Alfa Yayınları, 1. Bask1

Schlesinger, P. (1987). On national identity: Some conceptions and misconceptions criticized.Social Science Information, 26(2), 219-264.

Morley, D. ve Robins, K. (1997).Kimlik mekânları, (Çev: Emrehan Zeybekoğlu), İstanbul: Ayrıntı Yayınları, 1. Baskı

Sennett, R. (2010).Kamusal insanın çöküşü, (Çev: Serpil Durak ve Abdullah Yılmaz), İstanbul: Ayrıntı Yayınları, 3. Baskı

Smith, A. D. (1994). Millî kimlik, (Çev: Bahadır Sina Şener), İstanbul: İletişim Yayınları, 1. Baskı

Vural, Z. B. A. ve Bat, M. (2010). Yeni bir iletişim ortamı olarak sosyal medya: Ege üniversitesi iletişim fakültesine yönelik bir araştırma. Journal of Yaşar University,5(20), 3348-3382 http://dergipark.ulakbim.gov.tr/jyasar/article/view/5000066117/-5000061623 , (Erişim tarihi: 27 Aralık 2018).

\section{Kaynakça Bilgisi / Citation Information}

Çobanoğlu, Y. (2019). Değişen kamusallığın yeni "siyaset yapma" mekânı olarak sosyal medya - (Politik kimlikler ile kamusal haklar ilişkisi bağlamında twitter örneği). OPUS-Uluslararası Toplum Araştırmaları Dergisi,10(17), 696-737. DOI: 10.26466/opus.520312 